\title{
PlanetScope Imageries and LiDAR Point Clouds Processing for Automation Land Cover Mapping and Vegetation Assessment of a Reclaimed Sulfur Mine
}

\author{
Marta Szostak $^{1, *\left(\mathbb{D}, \text { Justyna Likus-Cieślik }^{2} \text { D }\right.}$ and Marcin Pietrzykowski $^{2}$ D \\ 1 Department of Forest Resource Management, Faculty of Forestry, University of Agriculture in Krakow, \\ 31-425 Krakow, Poland \\ 2 Department of Forest Ecology and Silviculture, Faculty of Forestry, University of Agriculture in Krakow, \\ 31-425 Krakow, Poland; justyna.likus@urk.edu.pl (J.L.-C.); m.pietrzykowski@urk.edu.pl (M.P.) \\ * Correspondence: marta.szostak@urk.edu.pl; Tel.: +48-12-662-5076
}

check for updates

Citation: Szostak, M.; Likus-Cieślik, J.; Pietrzykowski, M. PlanetScope Imageries and LiDAR Point Clouds Processing for Automation Land Cover Mapping and Vegetation Assessment of a Reclaimed Sulfur Mine. Remote Sens. 2021, 13, 2717. https://doi.org/10.3390/rs13142717

Academic Editor: Francisco Javier Mesas Carrascosa

Received: 31 May 2021

Accepted: 8 July 2021

Published: 10 July 2021

Publisher's Note: MDPI stays neutral with regard to jurisdictional claims in published maps and institutional affiliations.

Copyright: (c) 2021 by the authors. Licensee MDPI, Basel, Switzerland. This article is an open access article distributed under the terms and conditions of the Creative Commons Attribution (CC BY) license (https:/ / creativecommons.org/licenses/by/ $4.0 /)$.

\begin{abstract}
The present research investigated the possibility of using PlanetScope imageries and LiDAR point clouds for land cover assessment, especially vegetation mapping, in degraded and reclaimed areas. Studies were carried out on the former sulfur mine of Jeziórko located in Southeast Poland. In total, more than ca. 2000 ha of this mine area were reclaimed after borehole exploitation and afforestation. We investigated a total area of 216.72 ha. Integration of PlanetScope imageries and LiDAR point clouds processing offers the ability to derive information about the LULC classes and vegetation growth in the analyzed area and indicate the forest succession progress as an effect of the reclamation treatments. In the Jeziórko area, we identified coniferous forest (90.84 ha, $41.91 \%$ of the research area), broad-leaved forest (44.02 ha, 20.31\%), and transitional woodland shrub areas with herbaceous communities (77.96 ha, 35.97\%). The analyses focused on the detection and monitoring of the forest succession processes and obtaining the tree canopy profiles and characteristics of vegetation, i.e., the height and cover density.
\end{abstract}

Keywords: sulfur mine; spatial characteristic; ALS; image classification; forest succession; LULC classes

\section{Introduction}

An element that allows us to observe changes in the environment is the monitoring of the land use/land cover (LULC) and biomass dynamics [1]. Remote sensing technologies offer the ability to engage in geographic information system (GIS) analyses of different land categories and ecological processes, as well as discover trends and deliver timely insights. Generating the three-dimensional characteristics of vegetation in a semi-automated way will facilitate modeling and determine biomass and biometric features.

Forest succession monitoring in post-industrial, reclaimed areas is important for biodiversity preservation and bioenergy production, according to the forest ecosystem complexity and the diversity of LULC changes. It is sensible to explore the possibility of applying the newest technologies and geodata for this aim. The remote sensing approach is required to obtain a multidisciplinary view of the environmental research and policies related to climate changes due to the forest carbon dynamics information about the vegetation structure, which provides support for studies at degraded lands [2-4].

Afforestation is the most beneficial method for the reclamation and restoration of degraded ecosystems, mainly due to landscape redevelopment effects, soil and water prevention, and the dynamics of restored novel ecosystems [5]. Additional important benefits of the reclamation of forests include increases in biodiversity and biomass production $[5,6]$. The afforestation of post-industrial areas takes into account all the basic features of the environment (physical, chemical, and biological factors), and in the reclamation process, includes both technical and biological treatments [6]. Moreover, forests help to minimize 
the greenhouse effect and climate change [6-8]. Introduced tree stands in post-industrial areas play a significant role in the formation of specific microclimates and reforestation success. Appropriate control of vegetation growth, assessment of the productivity, including biomass, and the quality of the stands are indicators of the success of reclamation [6]. Thus, conducting research using remote sensing methods is very important for observing and conducting monitoring in reclaimed areas.

Remote sensing data and geoinformation technologies can support studies on the dynamics of LULC changes and vegetation progression [9-13]. Geospatial technologies offer a significant opportunity to execute large-scale studies on biomass mapping. PlanetScope's satellites include more than 150 nanosatellites and provide a unique dataset of Earth-based observations. With a unique combination of resolution, coverage, and frequency, PlanetScope can take daily images anywhere on the Earth with a $3 \mathrm{~m}$ resolution. PlanetScope provides the data necessary to develop geospatial insights about the speed of LULC changes. By providing the best possible images, PlanetScope allows one to monitor areas of interest, validate information on the ground, and discover relevant trends [14].

Light detection and ranging (LiDAR), especially airborne laser scanning (ALS), has great potential in studying vegetation formation [15-18] based on the relative values of tree and bush heights according to the ground surface. These values are determined through ground topography models, such as the digital terrain model (DTM) and digital surface model (DSM). The normalized DSM (nDSM) is the difference between DSM and DTM (nDSM = DSM - DTM) [19]. Airborne laser scanning technology collects 2D and 3D information that helps establish the spatial characteristics of vegetation [20-27]. It is highly important for the inventory and monitoring of afforestation and forest succession to provide information about biomass according to the EU Biodiversity Strategy [28], the National Program for Increasing Forest Cover [29], and actual information on forested grounds [30-32].

This research aimed to investigate the possibility of integrating remote sensing data and geoinformation technologies for the automated monitoring of afforested and secondary forest succession areas in post-industrial grounds. The study intended to determine the ability to derive spatial information for precisely mapping the range and structure of forest succession vegetation according to biodiversity and biomass monitoring in a postmining, reclaimed study area. The objective was to integrate land cover monitoring based on satellite imagery classification and the characteristics of vegetation based on LiDAR point clouds as 2D and 3D metrics to obtain information, e.g., about the height of the vegetation and the canopy cover. The fusion of satellite imageries with the ALS data provided an unprecedented dataset for observations, helping us better understand the land cover condition changes. The most important contributions of this study are its demonstration of the correctness of, and a possibility to integrate, various remote sensing materials, i.e., satellite images and airborne LIDAR point clouds, for the monitoring of forest phytocoenoses on degraded grounds.

\section{Study Area}

The research area (Figure 1 [33]) is located in Southeast Poland close to Tarnobrzeg county, in the municipality of Grębów. The former sulfur mine called Jeziórko is located at $50^{\circ} 32^{\prime} \mathrm{N} ; 21^{\circ} 47^{\prime} \mathrm{E}$. The study site covers 216.72 ha of the reclaimed and reforested area after sulfur exploitation via the Frasch process (borehole exploitation/underground sulfur melting). Forestry reclamation has also been applied in the area.

The former Jeziórko sulfur mine occupied more than 2140 ha, and more than half of the area (1179 ha) was reclaimed in 2010. For forestry, an area of about 700 ha was reclaimed, and the state forests (pl. PGL Lasy Państwowe) were granted land occupying a total area of 374 ha. The studied area is a forest complex located in a forestry district, occupying an area of over 216.72 ha. 

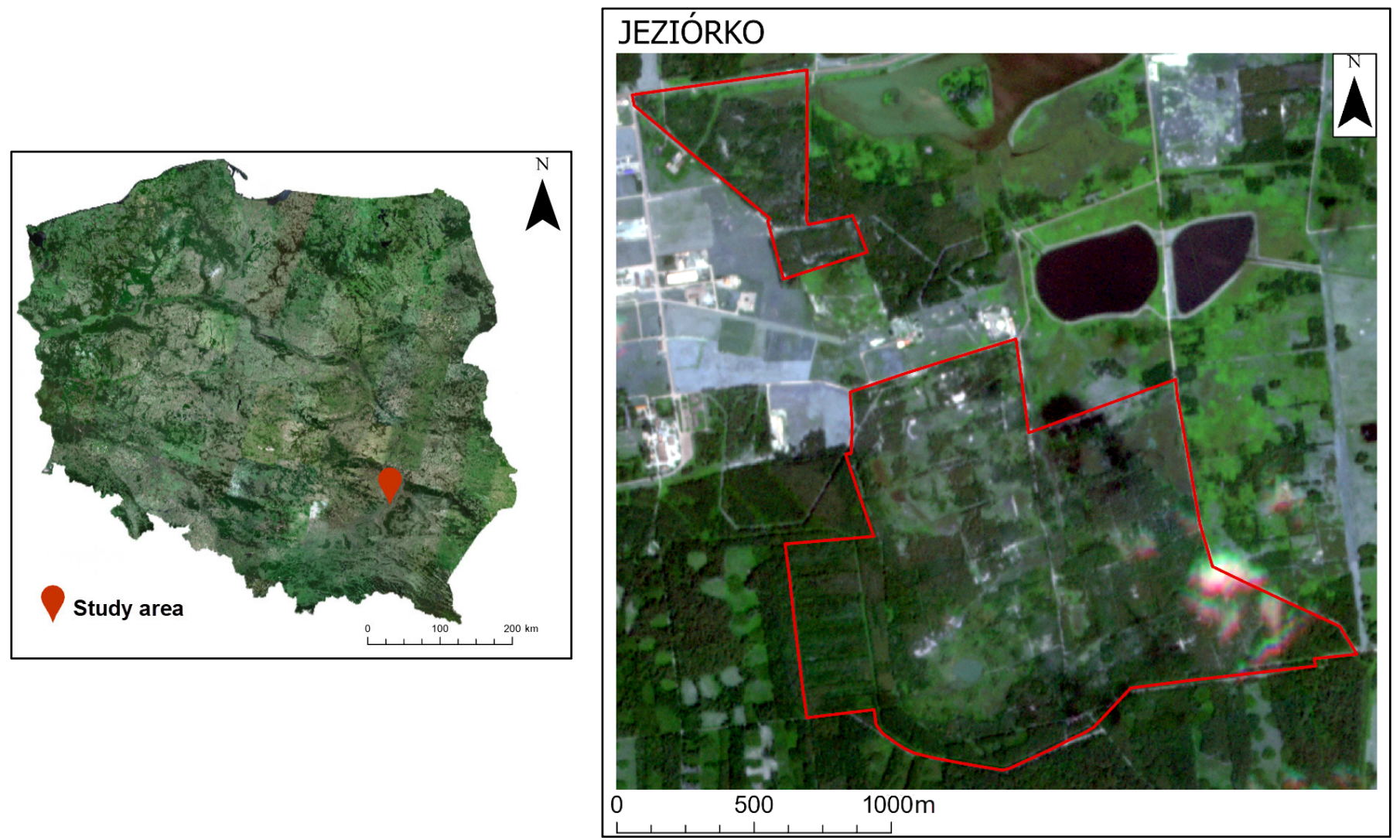

(a)

(b)

Figure 1. The research area: (a) general map of Poland with the localization of the study area; (b) analyzed area (red polygon) as a part of the former sulfur mine Jeziórko terrain (PlanetScope imagery, 2019).

Reclamation of this area consisted of, e.g., removing the infrastructure of the mine, improving the hydrographic and landscape conditions, neutralizing the $\mathrm{pH}$ of the sulfuric and highly acidic soils through liming (around $500 \mathrm{Mg} \mathrm{ha}^{-1}$ on average), fertilization (70 kg ha ${ }^{-1} \mathrm{P}_{2} \mathrm{O}_{5}, 60 \mathrm{~kg} \mathrm{ha}^{-1} \mathrm{~K}_{2} \mathrm{O}$ ), and sowing grass seeds [34]. Then, the area was developed for forestry. The area was mainly afforested with one-year-old seedlings of Scots pine (Pinus sylvestris L.) and with a smaller share of silver birch (Betula pendula Roth) and boreal oak (Quercus rubra L.) [35]. According to the forest management plan, the tree stands in the area are currently about 25 years old.

Reclamation of the land after sulfur extraction is generally characterized by a high degree of difficulty, especially in the case of land used for borehole mining, which causes large-scale environmental transformations, including overlapping chemical, geomechanical, and hydrological transformations [36]. The former Jeziórko sulfur mine is a very problematic area for plant adaptation because of the borehole sulfur exploitation method (Figure 2 [33]).

In the area of the former Jeziórko sulfur mine, chemical transformations were a large challenge for reclamation, which is a typical phenomenon for mines that use the Frasch method, which is accompanied by numerous spills of liquid sulfur, resulting from technological failures within the holes and pipelines (transmission installations [36]). Moreover, the liquefied sulfur spilled out uncontrollably from the technological landfills, strongly contaminating the adjacent areas [36]. Although the reclamation treatment was carried out with many expensive technical methods, the restored forest ecosystem still has hot spots (with a complete absence, or low degree, of vegetation cover) where the degree of sulfur contamination is high (up to $45,000 \mathrm{mg} \mathrm{kg}^{-1}$ ) [36]. The plants are thus forced to function in unnatural habitat conditions caused by soil, and surface and groundwater contamination caused by high sulfur concentrations. However, research in such areas offers an exceptional 
chance to expand our knowledge about the reactions of trees and stands, as well as other ecosystem components (including herbaceous plants) to environmental stress in the broad context of assessing the dynamics of forest ecosystems undergoing restoration [6,37-39].

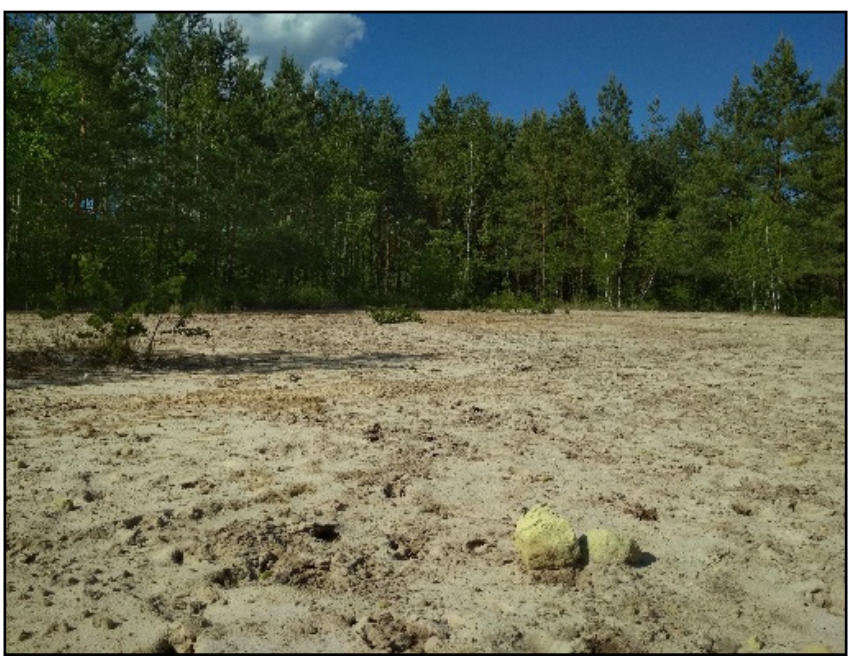

(a)

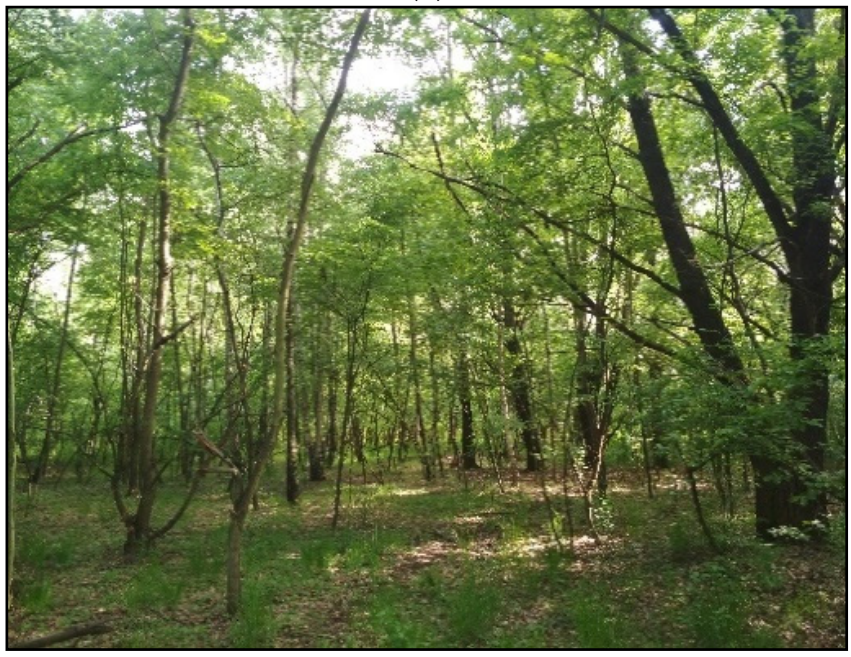

(c)

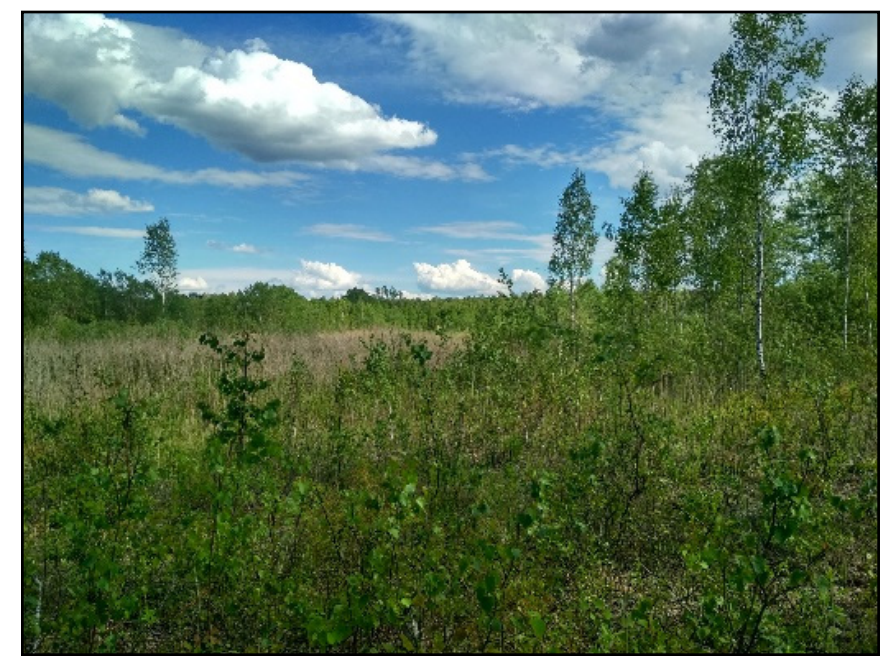

(b)

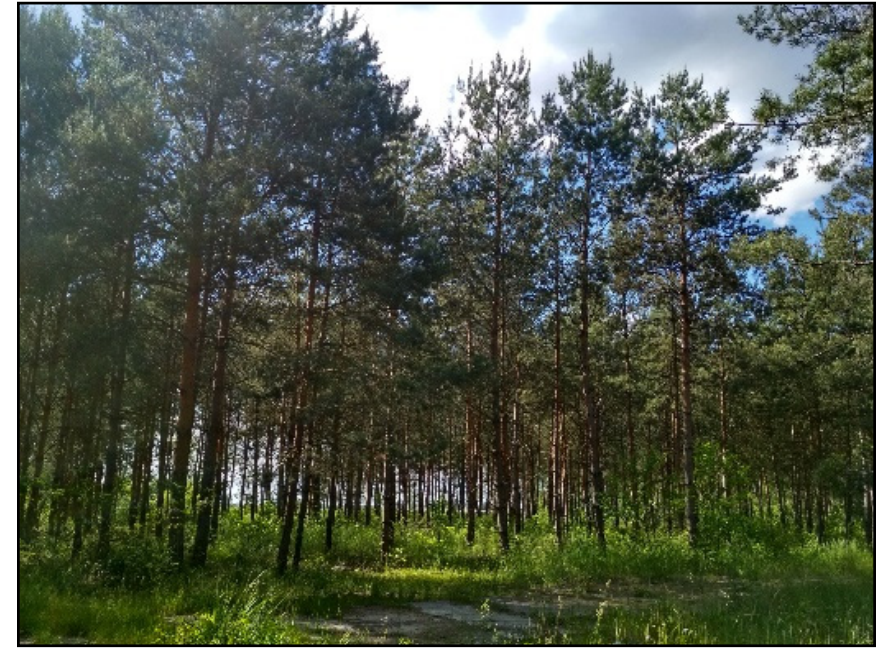

(d)

Figure 2. Scenes for the Jeziórko LULC classes: (a) mineral extraction sites, bare sand with sulfur contamination on the surface; (b) transitional woodland shrub, trees and bushes; (c) broad-leaved forest, i.e., oak, birch; (d) coniferous forest—scots pine.

\section{Materials and Methods}

The present research was carried out in 2019-2020 based on the following datasets:

- PlanetScope imagery (planet), date: 22 September 2019; channels: B-blue, G-green, R-red, and NIR; 3.0 m resolution; source: Planet's Education and Research (E\&R) Program [40];

- ALS point clouds; source: IT System for the Protection of Poland (pl. ISOK) project, point cloud density: $6 \mathrm{pts} / \mathrm{m}^{2}$; a minimum of 4 reflections; the altitude accuracy (mean error) of the ALS point clouds after alignment was $\leq 0.15 \mathrm{~m}$; situational accuracy $\leq 0.50 \mathrm{~m}$;

- Orthophotomaps and cadastral data.

The PlanetScope imagery classification was performed using the photointerpretation key (RGB and Color InfraRed (CIR: R, G, NIR)) composition prepared during the field study (2019) using a Spectra Precision GNSS receiver. We chose points based on 5 classes 
(Figure 3 [33]): mineral extraction sites (places without vegetation cover/insufficient reclamation), broad-leaved forest, coniferous forest, transitional woodland shrub, and water. In Figure 3, we provide examples of 5 classes marked with circles larger (for visibility) than the real measured field points. Exploitation was carried out throughout the entire area, and there were 8000 holes in about 2000 ha. Reclamation was successful in most of the area but not in certain places. Figure 3 presents an example mineral extraction site after the reclamation process that is still without vegetation cover.

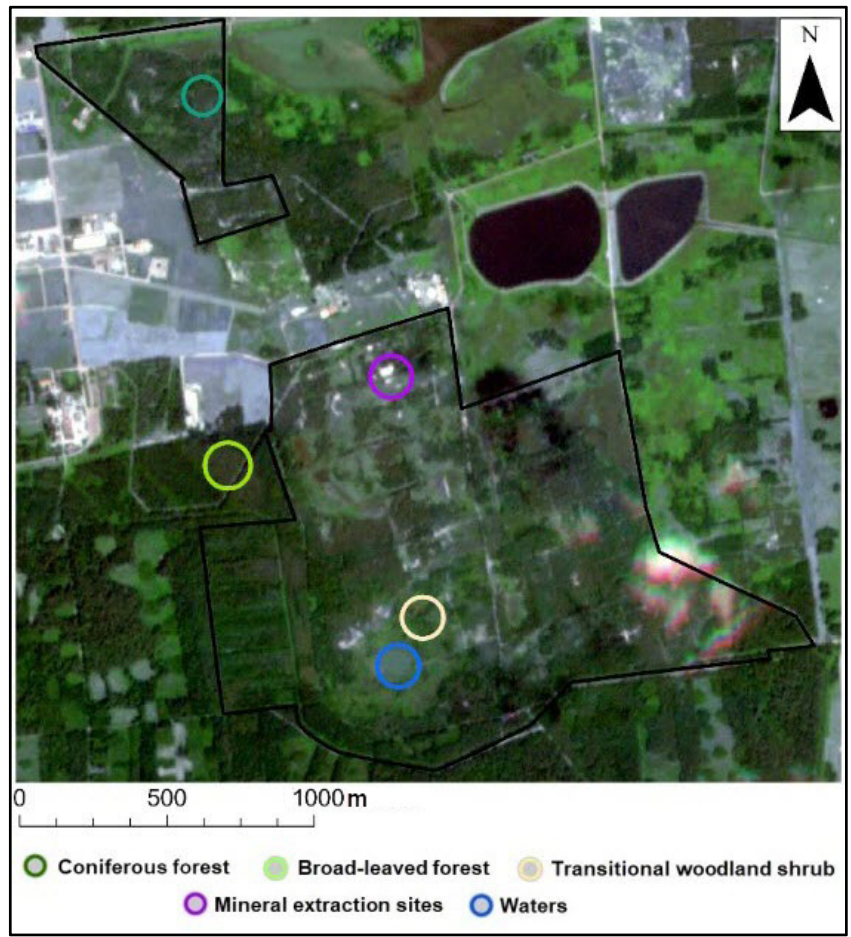

(a)

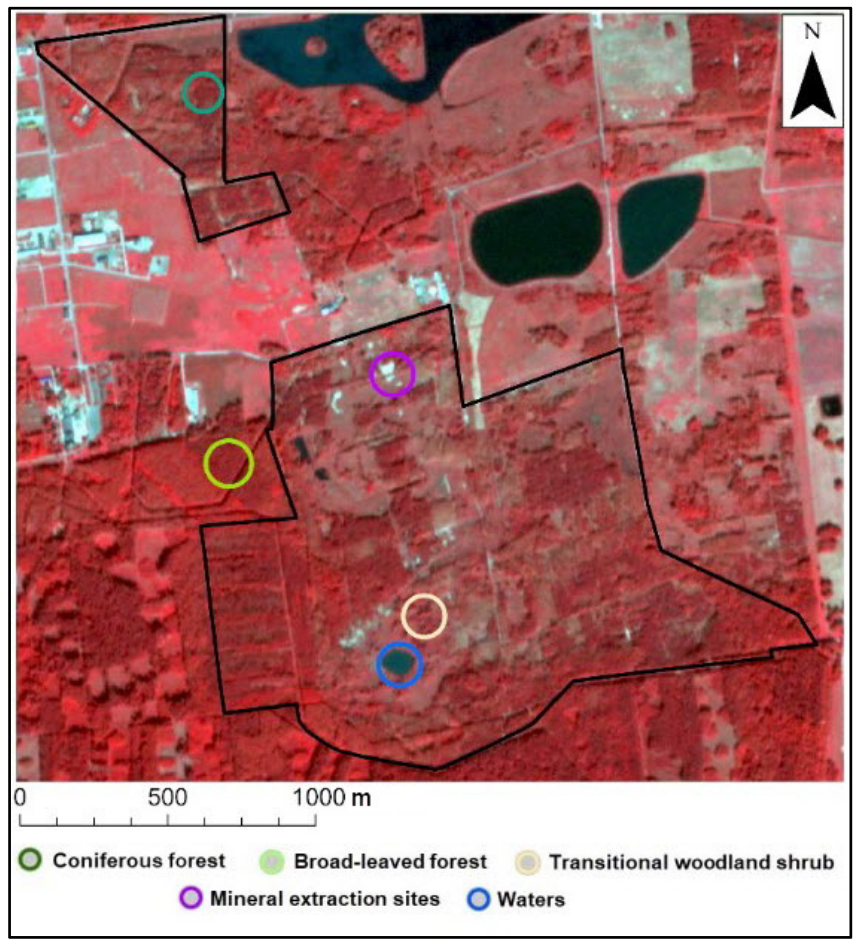

(b)

Figure 3. Examples of LULC classes for the Jeziórko former sulfur mine research area: (a) RGB; (b) CIR color composition (source: Planet imagery, 2019).

The preliminary processing of the PlanetScope imagery (the product was orthorectified with 4-band imagery featuring geometric, radiometric, and atmospheric corrections) was carried out to create the color compositions of RGB and CIR. Images were classified using the methods (ArcGIS Pro, Esri) of random trees, support vector machine, and maximum likelihood. Tree classifiers were tested to choose the better one. The total number of training areas (area of interest (AOI)) was around 600 [33] (Figure 4): broad-leaved forest, 168 samples (3952 pixels, $12.32 \%$ of the total number of pixels), and coniferous forest, 205 (8164 and 25.45\%, respectively); transitional woodland shrub, 136 (10,018 and 31.23\%, respectively); mineral extraction sites, 46 (558 and 1.74\%, respectively), and water, 43 (9383 and $29.25 \%$, respectively).

The image classification results were assessed using the create accuracy assessment points tool in ArcGIS Pro. Classes were verified based on the CIR and RGB color composition in PlanetScope and orthophotomaps. Based on the validation points (total number: 500, different than the training points), using the compute confusion matrix tool, provided the following parameters: producer accuracy, user accuracy, and overall accuracy. The kappa coefficient was also calculated. As the final step of the processing, we used the generalization tools of boundary clean and majority filter (ArcGIS Pro).

The LiDAR point cloud processing began by deriving the models: DTM (tool: GridSurface Create), DSM (canopy model) in FUSION Version 3.50 (Pacific Northwest Research Station: Seattle, WA, USA) [41], and normalized DSM (nDSM = DSM - DTM) using map 
algebra (ArcGIS Pro). For both models, DTM and DSM were rendered in grayscale (hillshade). There are many vegetation structural metrics needed to understand the overall vegetation structures of different forest types that can be derived from LiDAR data to provide details about the vertical and horizontal variations in the forest structure. In this study, we use the metrics of height, the standard deviation of height, and cover density (canopy cover), but one can also calculate the canopy relief ratio, penetration coefficient, density at different height strata, etc. The height of the vegetation was calculated as the 95 $5^{\text {th }}$ percentile [24] and presented as a value in a raster form (tools: GridMetrics and CloudMetrics, FUSION software). The cover density (tool: Cover) was also calculated as the values from $0 \%$ to $100 \%$. The vertical vegetation structure is presented as a histogram (density metrics) of the total number of laser points reflected from the vegetation in defined intervals, i.e., a $1 \mathrm{~m}$ vertical interval for the sequent raster cells [41].

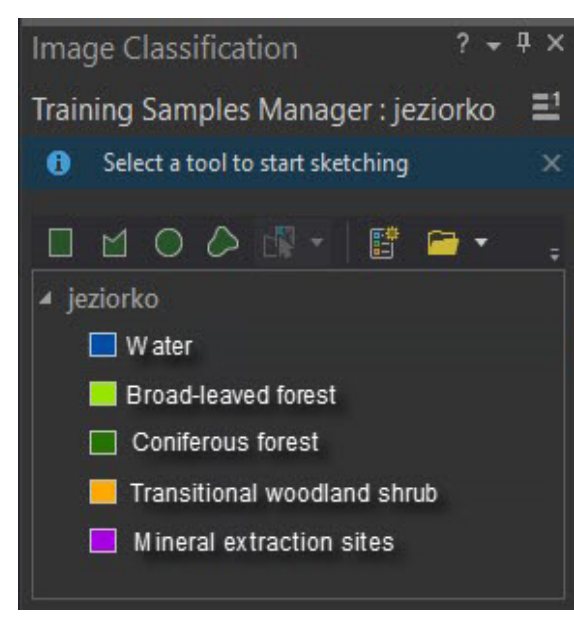

(a)

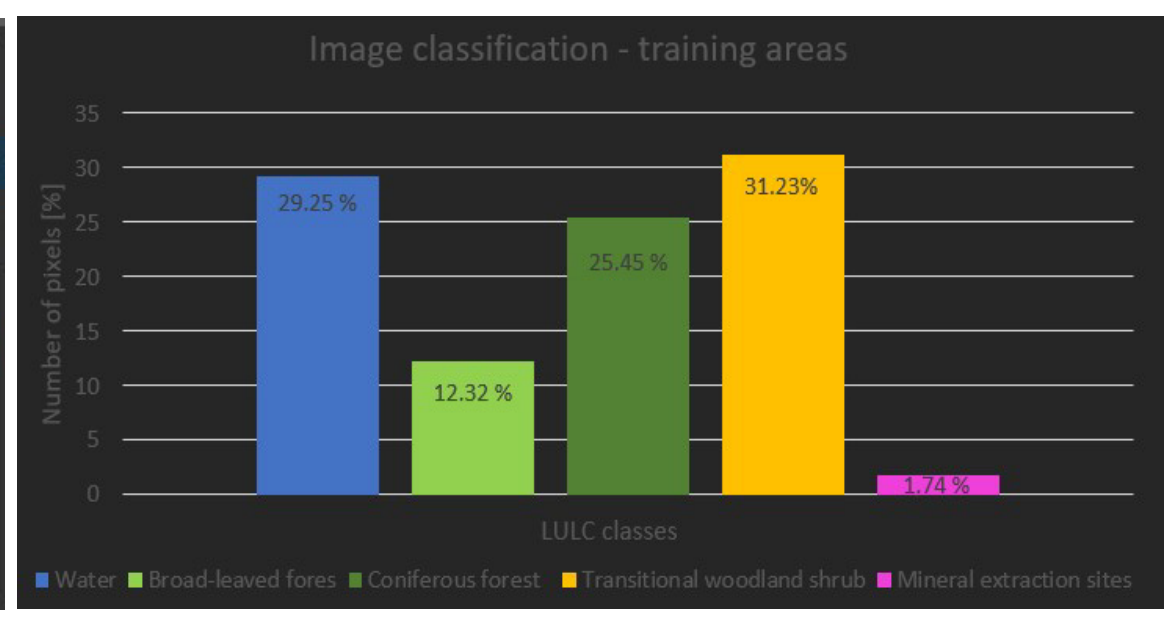

(b)

Figure 4. Image classification: (a) training samples manager; (b) the total number of training areas (Arc GIS Pro, Esri).

\section{Results}

The morphometric characteristics of the Jeziórko research area are presented as grayscale shaded hills in the DTM and DSM (Figure 5 [42]) created based on the ALS data. The lowest part of the analyzed area is $146 \mathrm{~m}$ AMSL, and the highest is $154 \mathrm{~m} \mathrm{AMSL;}$ thus, this is a relatively flat area.

The best results (best assessment parameters) of PlanetScope image classification were obtained using the random trees method. The LULC classes derived using PlanetScope image classification are presented in Figure 6. The assessment parameters for the random trees method obtained the following values: producer accuracy, 94.56\%; user accuracy, 94.32\%; and total estimated overall accuracy, 92.81\% (Table 1). The kappa coefficient had a value of $90.11 \%$ [33]. The results of image classification using the random trees method cropped to the Jeziórko research area are presented in Figure 7.

The results of the PlanetScope image classification determined that the primary land cover includes forested areas (Table 2): coniferous forest, broad-leaved forest, and transitional woodland shrub [33]. In total, forested grounds covered $95.19 \%$ of the research area. Other classes include mineral extraction sites and water.

The spatial parameters (2D and 3D) of the vegetation were derived from the ALS point clouds (Figure 8$)$, the height of vegetation ( $95^{\text {th }}$ percentile), the standard deviation of height, and canopy cover (cover density, values of 0-100\%) [42-44]. The parameters are presented as raster maps (pixel size: $1.0 \mathrm{~m}$ ). Figure 8 shows the effect of ALS data processing for the spatial biomass indicators of vegetation in the Jeziórko area. 


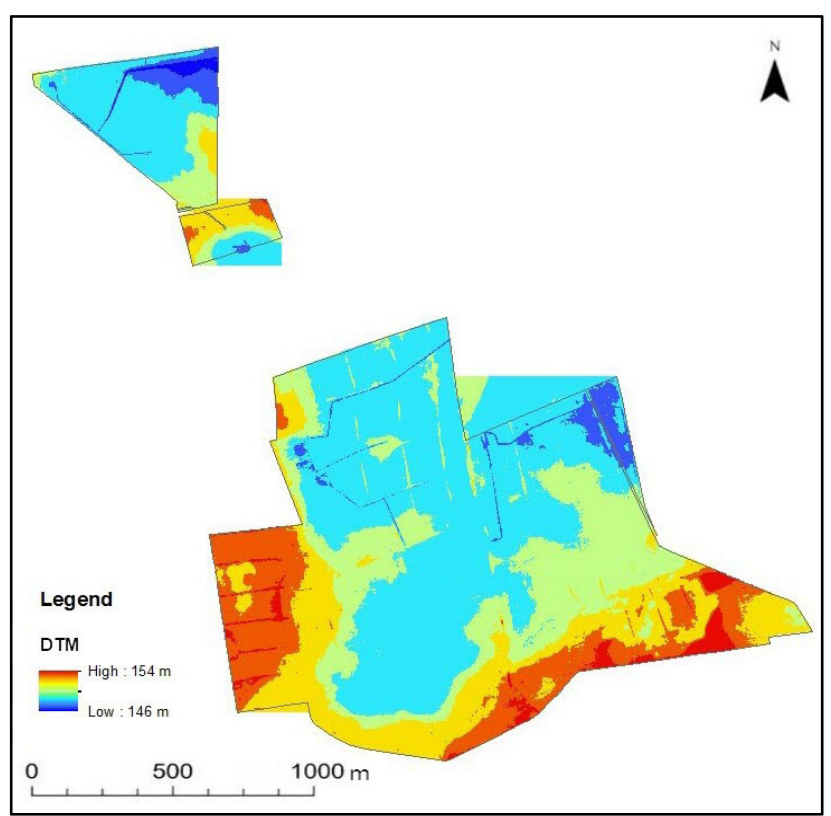

(a)

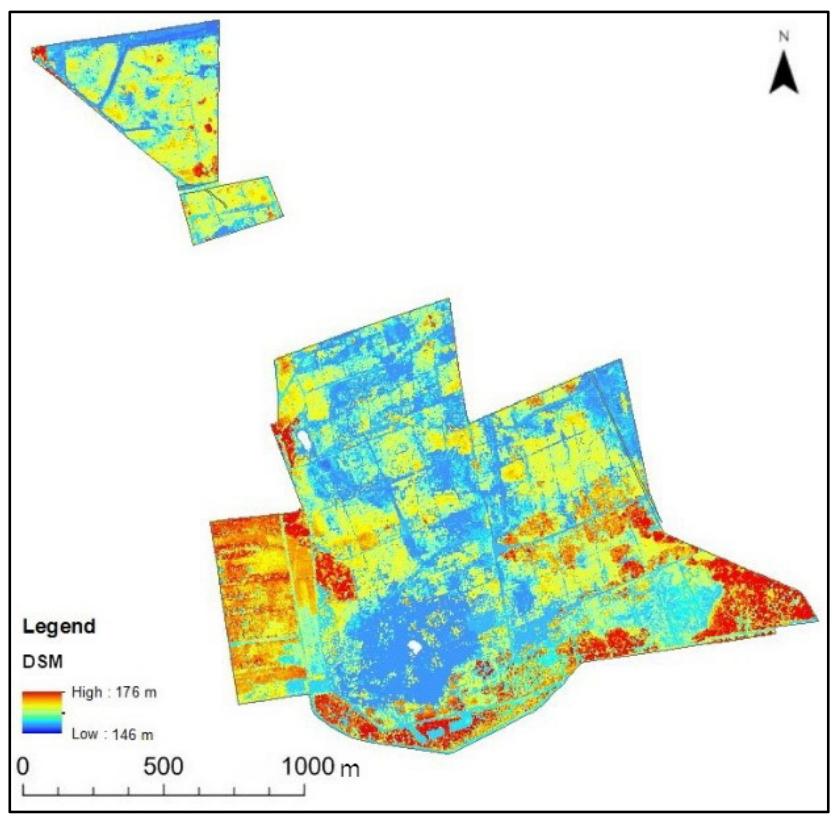

(c)

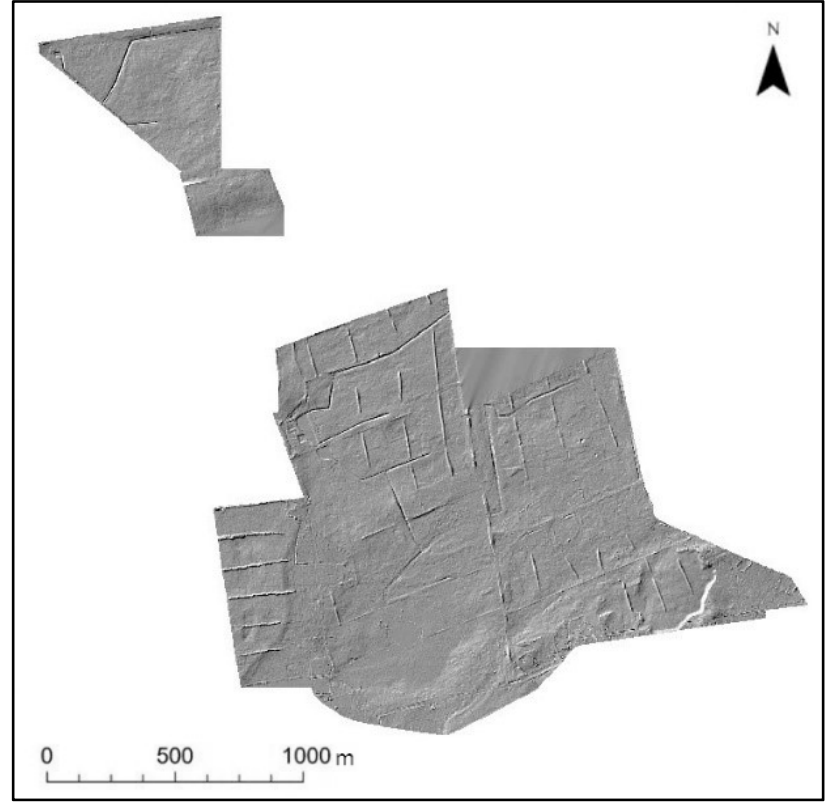

(b)

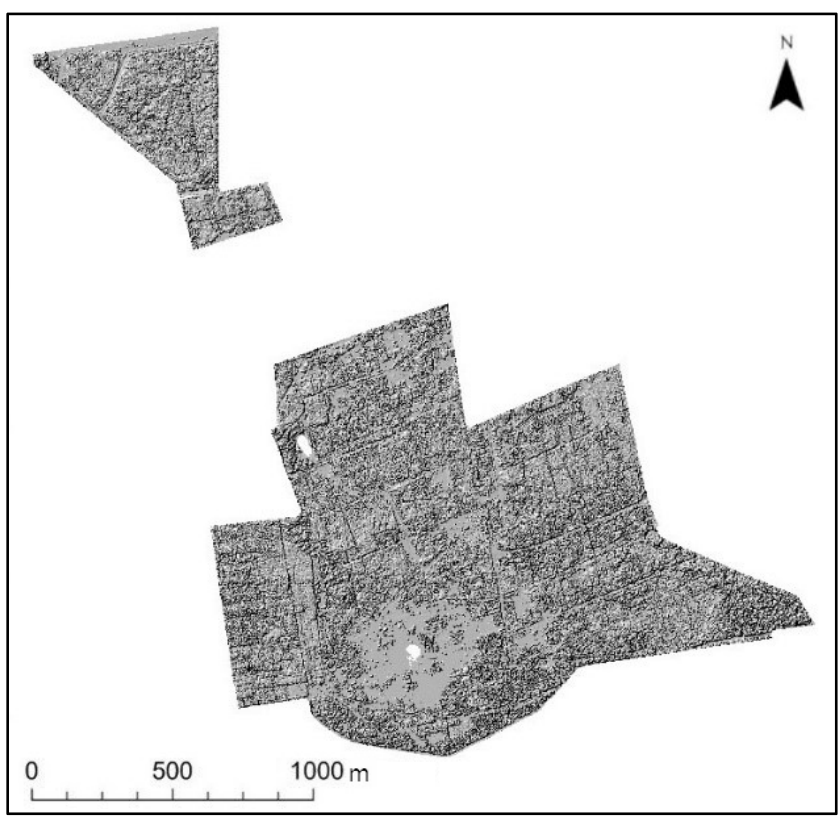

(d)

Figure 5. Jeziórko area: (a) digital terrain model (DTM); (b) DTM hillshade; (c) digital surface model (DSM); (d) DSM hillshade.

Mean values of height vegetation calculated based on ALS data take the following values in height classes: low vegetation, $4.4 \mathrm{~m}$ (standard deviation $=0.9 \mathrm{~m}$ ): medium vegetation, $9.2 \mathrm{~m}(\mathrm{SD}=1.1 \mathrm{~m})$, and high vegetation, $19.8(\mathrm{SD}=1.0 \mathrm{~m})$. The maximum value of height calculated as the $95^{\text {th }}$ percentile was $24.0 \mathrm{~m}$.

Figures 9-11 show the detailed parameters of vegetation (in different stages of growth) as histograms and profiles from the ALS data (vegetation are green points, and the ground is pink). Examples are shown for low (transitional woodland shrub), medium, and high vegetation (broad-leaved forest and coniferous forest) [42]. 


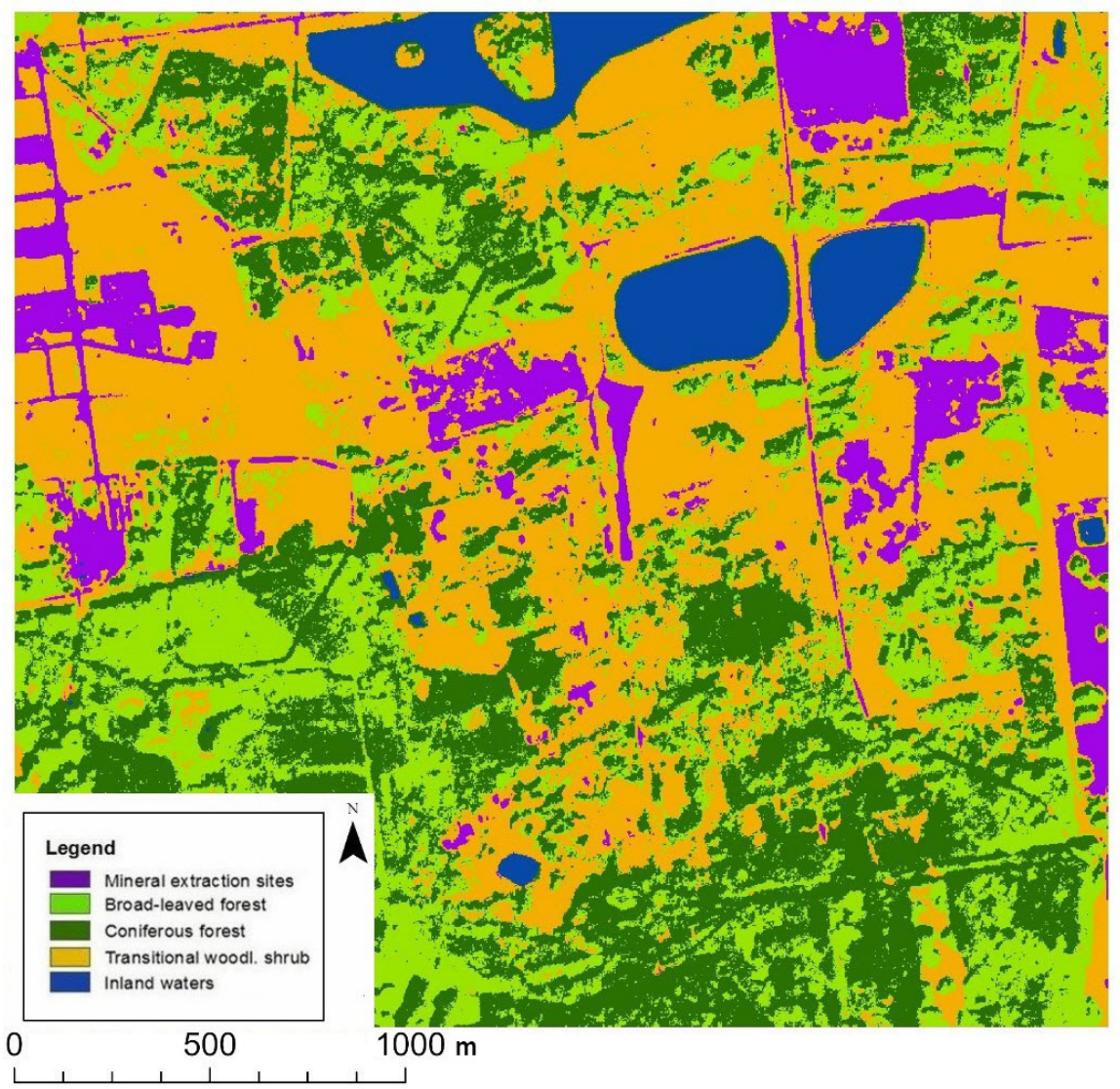

Figure 6. The results of the PlanetScope image classification, random trees method.

Table 1. The assessment parameters for the random trees method. Total estimated, overall accuracy (OA) was shown as a bold value.

\begin{tabular}{|c|c|c|c|c|c|c|c|}
\hline $\begin{array}{c}\text { Land Cover } \\
\text { Classes }\end{array}$ & $\begin{array}{c}\text { Mineral } \\
\text { Extraction } \\
\text { Sites }\end{array}$ & $\begin{array}{c}\text { Broad- } \\
\text { Leaved } \\
\text { Forest }\end{array}$ & $\begin{array}{c}\text { Coniferous } \\
\text { Forest }\end{array}$ & $\begin{array}{c}\text { Transitional } \\
\text { Woodland } \\
\text { Shrub }\end{array}$ & Water & Total & $\begin{array}{c}\text { User } \\
\text { Accuracy (\%) }\end{array}$ \\
\hline $\begin{array}{c}\text { Mineral } \\
\text { extraction sites }\end{array}$ & 37 & 0 & 0 & 1 & 0 & 38 & 97.37 \\
\hline $\begin{array}{l}\text { Broad-leaved } \\
\text { forest }\end{array}$ & 0 & 114 & 2 & 14 & 0 & 130 & 87.69 \\
\hline Coniferous forest & 0 & 5 & 118 & 9 & 0 & 132 & 89.39 \\
\hline $\begin{array}{c}\text { Transitional w. } \\
\text { shrub }\end{array}$ & 3 & 1 & 1 & 173 & 0 & 178 & 97.19 \\
\hline Water & 0 & 0 & 0 & 0 & 23 & 23 & 100.00 \\
\hline Total & 40 & 120 & 121 & 197 & 23 & 501 & 94.32 \\
\hline $\begin{array}{c}\text { Producer } \\
\text { Accuracy (\%) }\end{array}$ & 92.50 & 95.00 & 97.52 & 87.82 & 100.00 & 94.56 & $\mathrm{OA}=92.81$ \\
\hline
\end{tabular}

Table 2. Land cover classes, total values are a result of the PlanetScope classification.

\begin{tabular}{ccc}
\hline Land Cover Classes & Area (ha) & Percentage (\%) \\
\hline Mineral extraction sites & 3.04 & 1.40 \\
Broad-leaved forest & 44.02 & 20.31 \\
Coniferous forest & 90.84 & 41.91 \\
Transitional woodland shrub & 77.96 & 35.97 \\
Water & 0.86 & 0.40 \\
Total & 216.72 & 100.00 \\
\hline
\end{tabular}




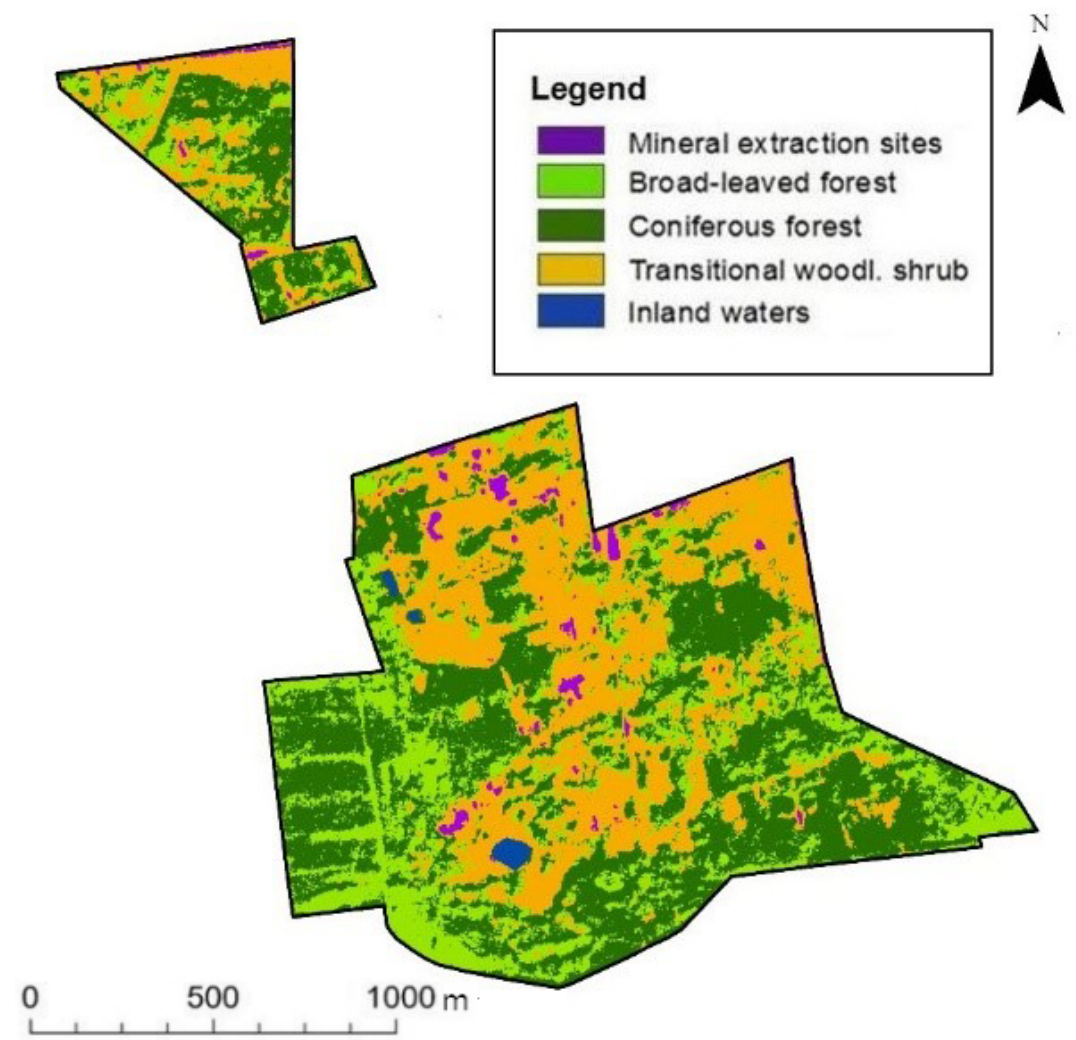

Figure 7. The results (random trees method) of image classification cropped to the Jeziórko research area.

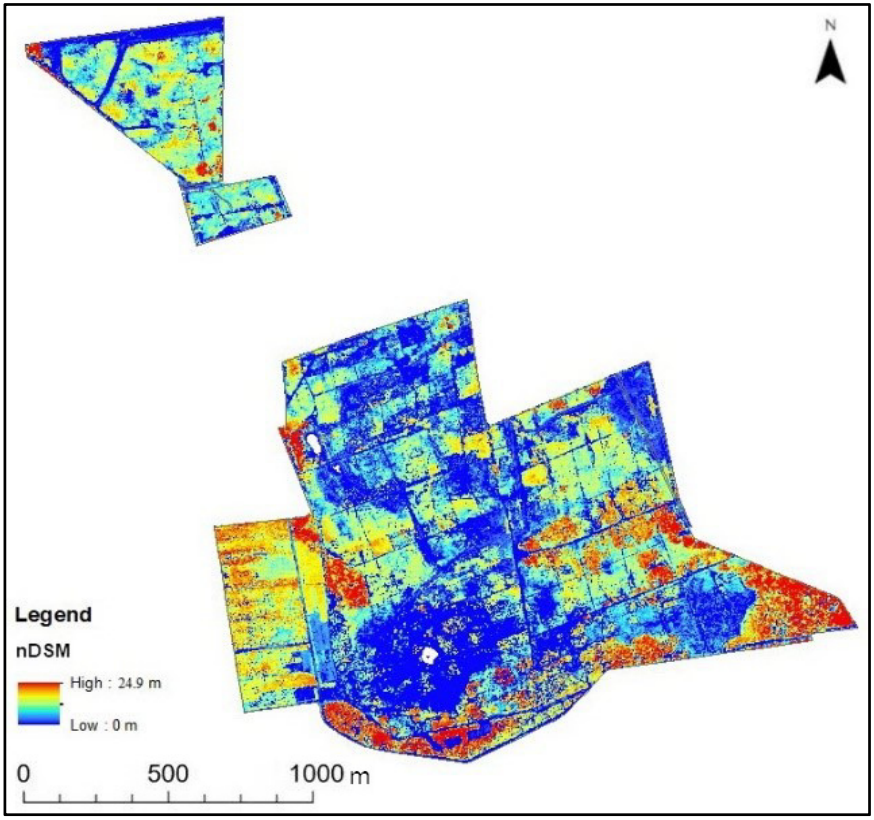

(a)

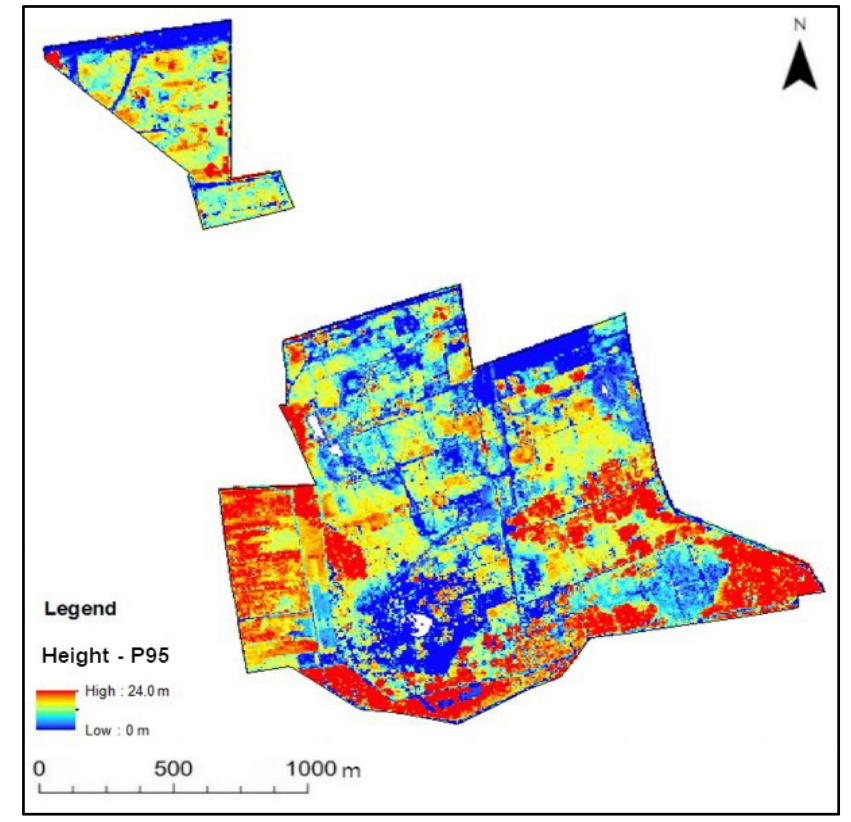

(b)

Figure 8. Cont. 


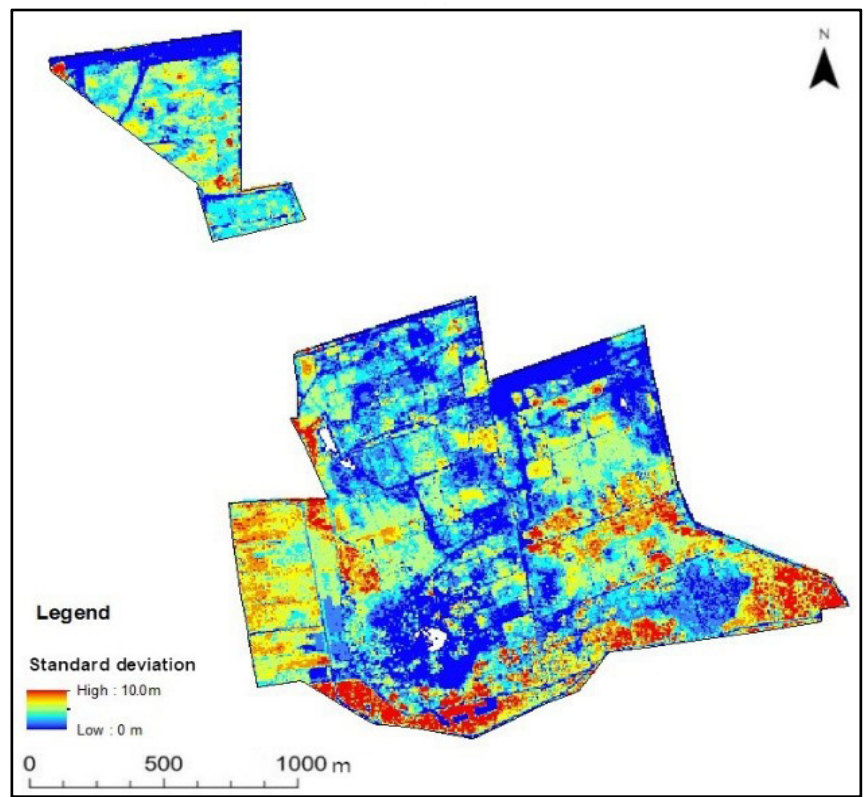

(c)

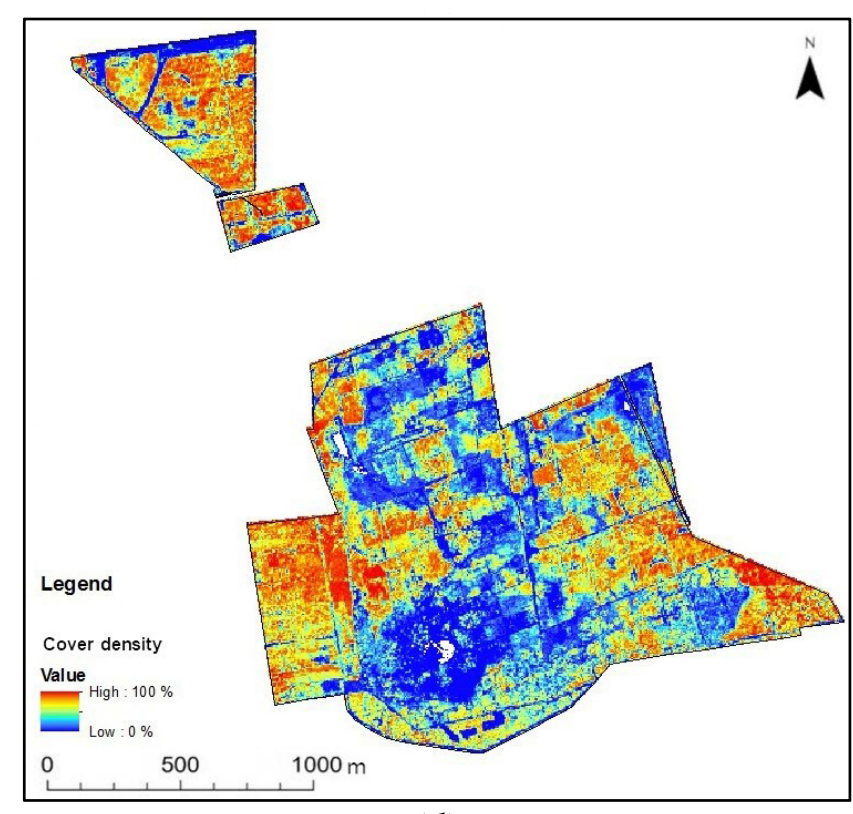

(d)

Figure 8. LiDAR parameters: (a) normalized DSM; (b) height of vegetation (95 $5^{\text {th }}$ percentile); (c) standard deviation of height; (d) cover density (with a value of $0-100 \%$ ).

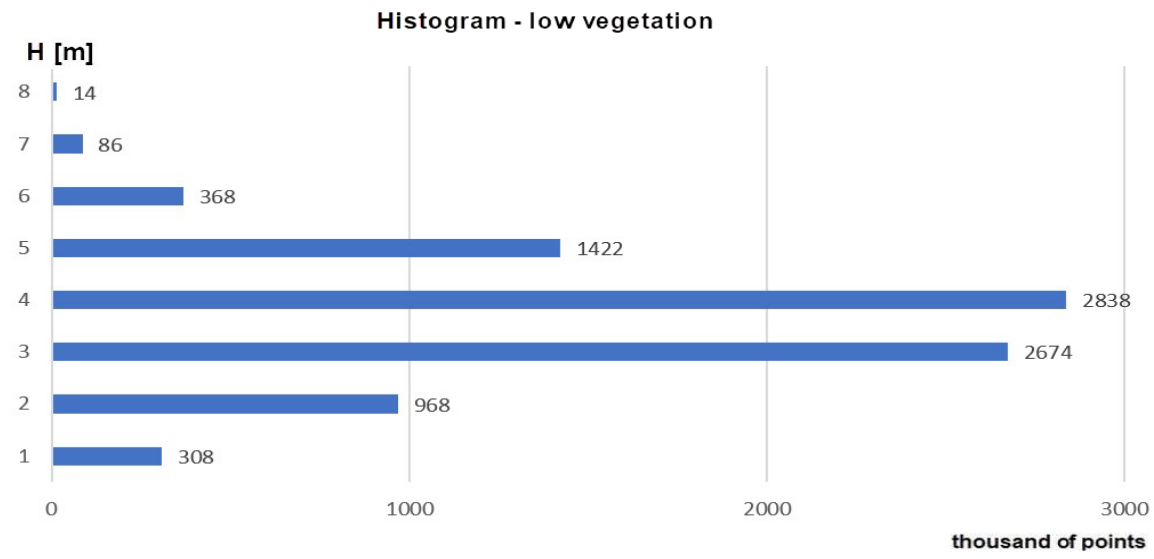

(a)

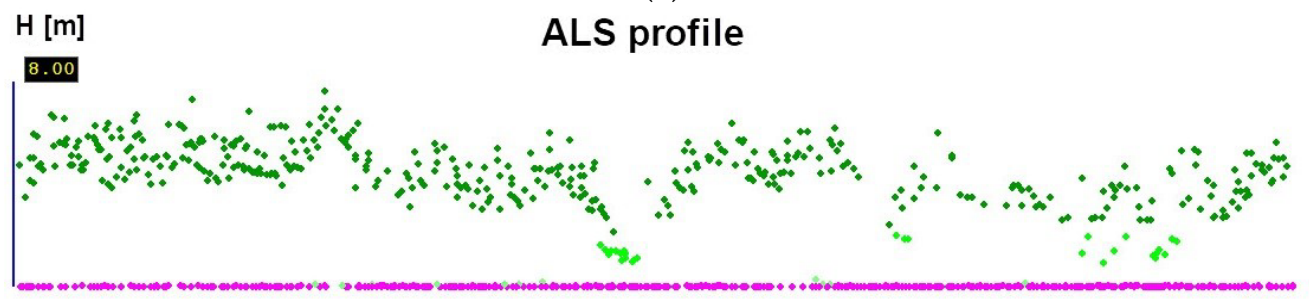

(b)

Figure 9. Low vegetation: (a) histogram; (b) profile. 


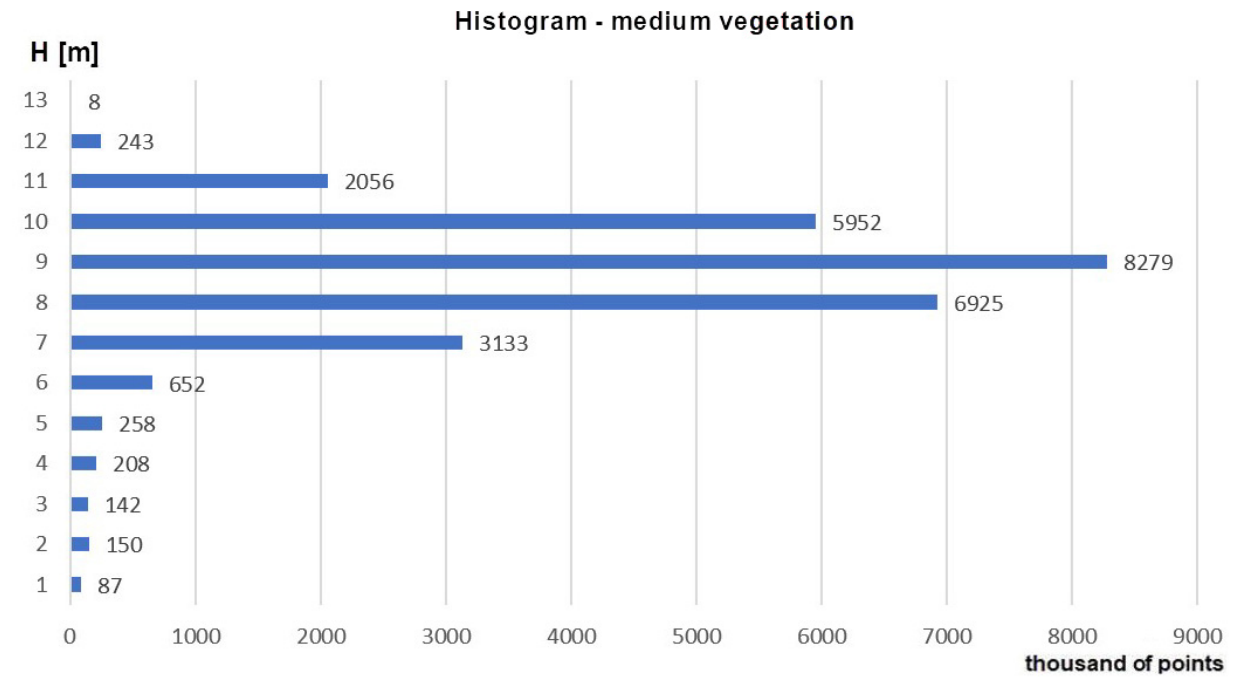

(a)

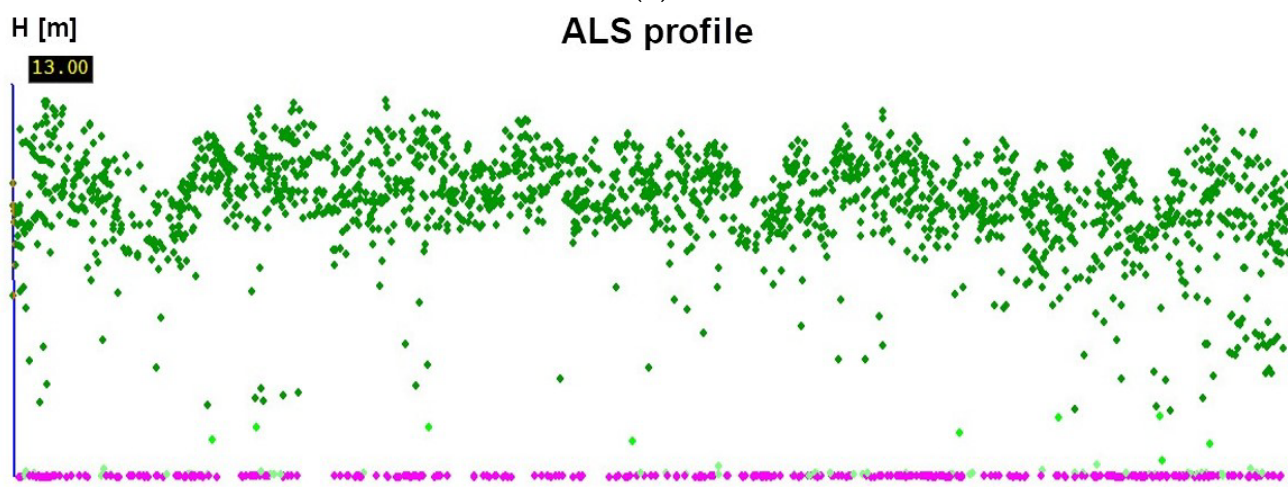

(b)

Figure 10. Medium vegetation: (a) histogram; (b) profile.

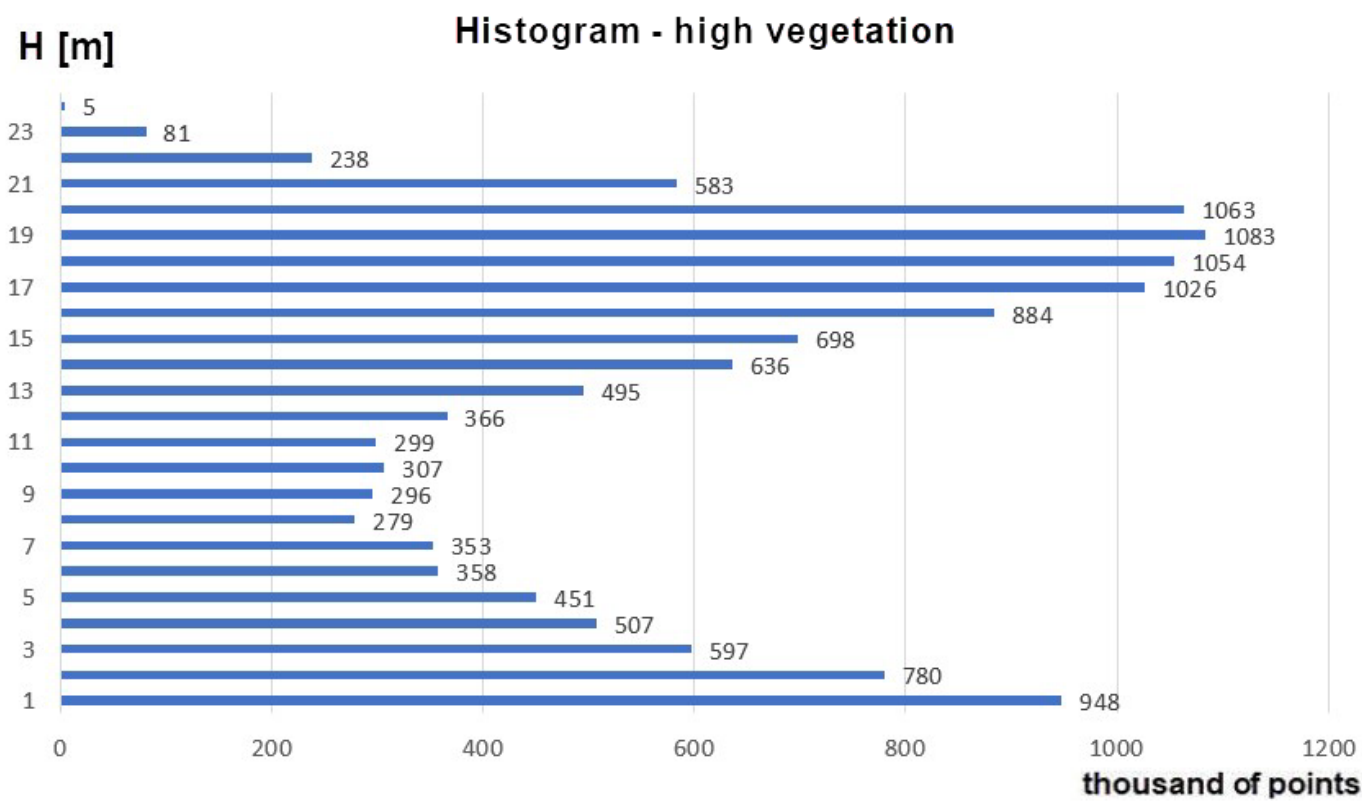

(a)

Figure 11. Cont. 


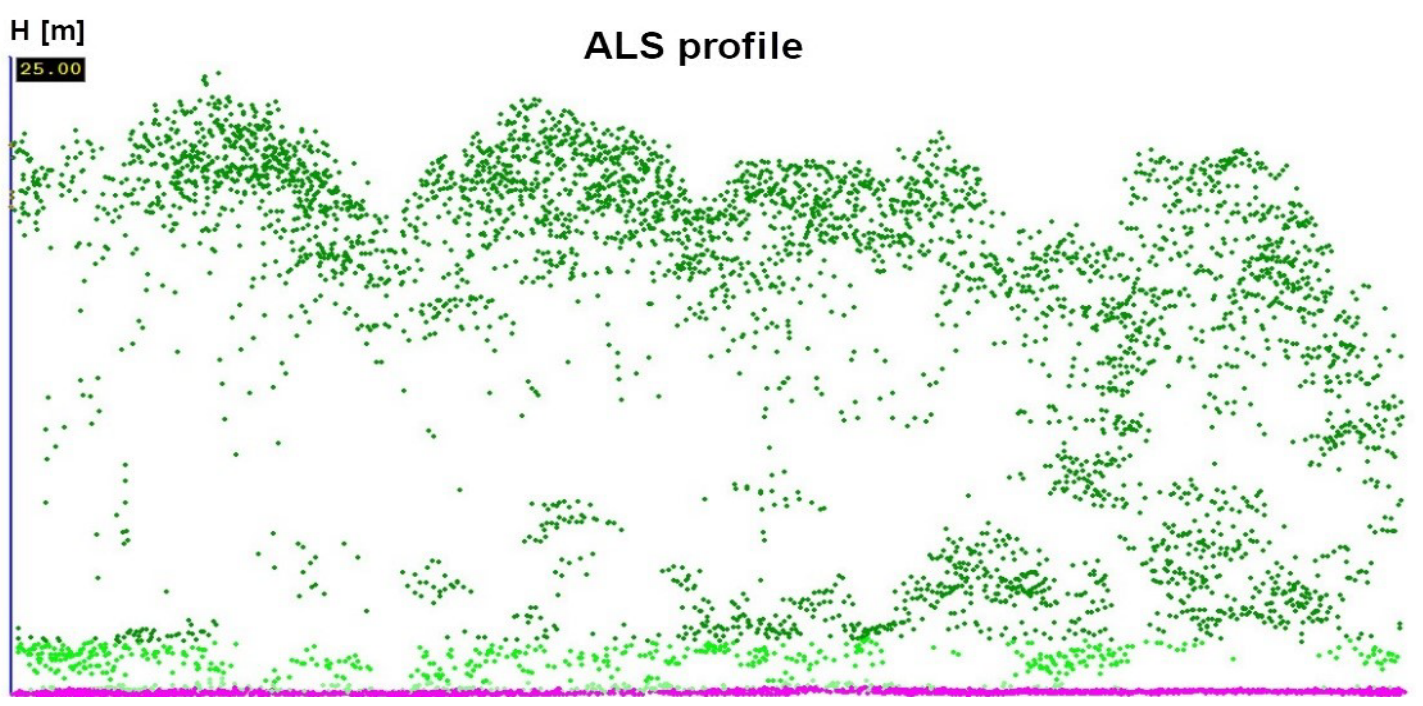

(b)

Figure 11. High vegetation: (a) histogram; (b) profile.

\section{Discussion}

Remote sensing methods offer the ability to derive objective information about vegetation in reclaimed areas [45-50]. The automated detection and monitoring of afforested and forest succession areas in post-industrial grounds are vital based on the analyzed results of the reclamation process. Mapping land/land cover changes are also significant in terms of land degradation assessment and biomass monitoring for post-mining areas. The spatial parameters (2D and 3D metrics) and biometric features help forest phytocoenoses observation [51-54]. A suitability assessment of vegetation is also important to create a forest on post-industrial grounds and solve the problem of the reconstruction and development when forming forests, according to their presence in the environment and the landscape [55-58].

The development of vegetation and plant conditions in reclaimed areas provides the basic elements for assessing the dynamics of the restored, post-industrial ecosystem. Plant succession largely depends on the landscape soil formation process and its parameters (soil is the critical component that interacts with other elements of the forest ecosystem) [59]. In the assessment of the forest reclamation success, the following factors are used: the size of the area covered with vegetation and the time of its overgrowth. Ecology uses indicators related to the development of plant communities (e.g., biomass, community diversity, the abundance of species, forest species presence, and species abundance and share) $[6,60]$. The differences between natural soil and technosols involve the lack of soil organic matter, frequent acidification or alkalization, salinity, heavy metal concentrations, compaction, disturbed quantitative ratios of macroelements, etc. Often, post-industrial areas are characterized by spatial variability and a significant dynamism of changes in the soil properties of newly formed habitats [61]. For these reasons, technogenic soils are often not able to meet the nutritional needs of the trees harmoniously [62]. The occurrence and degree of coverage in the reclaimed area by vegetation and the conditions of the trees are an important part of afforestation or natural succession. Moreover, the state of plant mineral nutrition is an important element in the evaluation of restoring ecosystems under post-industrial conditions. Vegetation entering succession or introduced as part of afforestation is an indicator of the success of reclamation.

Studies of how the sulfur mine caused environmental changes in the analyzed area and how the reclamation treatments affect the afforestation vegetation growth were presented in previous studies $[35,36]$. In the present study, precise information about actual LULC classes, especially the spatial range of the vegetation, was prepared using an image classification of the PlanetScope imageries. The former Jeziórko sulfur mine area showcases 
a dynamic increase in its forested areas. Previous studies [43,44,63-65] based on analyses using Landsat 7 (2000), Landsat 8 (2013), and Sentinel-2 (2016) image classification, as well as orthophotomaps vectorization (2009), showed the general range and total value of forested grounds. Using the PlanetScope image analyses in this study, we obtained more precise information about the location, range, and percentage of the total value of forested areas. Forested grounds assumed a total value of around 95\% in the research area, but around $35 \%$ of this value involves transitional woodland shrub, which indicates the ongoing process of forest succession and vegetation in the Jeziórko study area. Based on the ALS data analyses, we provided a precise tree canopy profile, and the vertical vegetation structure provided precise information according to the biomass of forested phytocoenoses. Increases in comparability, reliability, and efficiency are some benefits of using PlanetScope satellite imageries, LiDAR data, and automated procedures for detecting and monitoring afforestation. With a unique combination of high resolution and frequency, using PlanetScope and LiDAR data processing, we were able to provide the objective information necessary to produce geospatial insights into LULC classes in the reclaimed areas.

In this study, we indicated the sequence of automated PlanetScope image processing and LiDAR point cloud metrics determination to obtain precise, objective, and validated information about the location, range, and spatial structures of the trees and shrubs formed or developed in post-industrial areas. Using PlanetScope imageries, we observe more precise characteristics of the transitional woodland shrub and broad-leaved or coniferous forest. PlanetScope satellite constellation utilization is expected to expand in the future, so this research is useful for readers who are considering the use of satellite data in the future.

The authors investigated the possibility of applying the newest PlanetScope imageries for automated LULC classification in the reclaimed Jeziórko area, as forest succession mapping is an important issue in this post-mining terrain. Using ALS point clouds allowed us to analyze the vegetation canopy profiles and metrics and, in this case, study automation for monitoring the forest succession process [66-68]. We stated that image processing and LiDAR point clouds provide accurate information about forested areas. Alternatives for ALS data include point clouds derived using unmanned aerial vehicles (UAVs) [69-72]. The stereo-matching method of UAVs and aerial photographs offer management, monitoring, and precise information about reclaimed areas [73-75]. In this case, the availability of a precise DTM derived from ALS that does not change for many years is important. Once obtained, e.g., from the ISOK project (ALS campaign in Poland), these data can be used for many studies. The automated ALS point cloud processing method presented in this study offers the possibility for vegetation growth assessment. Cyclic PlanetScope imageries and LiDAR data processing can provide the time-series mapping LULC changes taking place in reclaimed post-mining areas. Further, regular airborne scanning or UAV campaigns can derive the spatial characteristics of biomass.

The study of individual environmental elements conducted at the former Jeziórko sulfur mine (for soil, surface water, plant reaction, and their nutritional conditions), supplemented with the use of modern geomatics technologies, enables a composite evaluation of the state of the restored ecosystem. Among other factors, land-cover categories were distinguished (with pine and birch woody vegetation in stands and areas without vegetation, the so-called degraded categories), which may allow for the precise positioning and establishment of permanent control areas in the field for detailed physicochemical tests. In addition, the use of modern technologies allowed monitoring of the conditions in areas of former sulfur mining at the Jeziórko mine (without having to explore the entire area), where excessive sulfur concentrations in the soil create the area a dynamic system. The present research on Jeziórko showed an increase in forested areas. Therefore, we conclude that automated remote sensing processing was useful for mapping the 3D characteristics of the analyzed afforested post-industrial areas. A combination of satellite imageries and LiDAR data provided reliable results and may be used for the automated monitoring of forest succession in this degraded area in the future. 
Landscape and vegetation information and land cover mapping history can be used to assess the long-term restoration habitats according to the directions of reclamation, especially for woodland afforestation. The ecology of land-use and land-cover changes help explain the failed parts of the reclaimed area and can help outline the sustainable management of the analyzed area. An integrated spatial policy is important for effective post-industrial ecosystem management and planning afforestation for the sustainability and utility of the reclaimed area. There is a need to focus on the conservation of increasing habitats and ecosystems and remote-sensed data can help with this issue. Reclamation issues provide benefits that deliver ecosystem services to human society and help us better understand the importance of LULC changes in sustainable land planning and the development of vegetation in post-industrial areas [76-78].

\section{Conclusions}

Knowledge about degraded and reclaimed areas was collected at many spatial scales and with miscellaneous methods, as this is an important issue for environmental management. The vegetation growth data help to establish the monitoring reclamation treatments and functional changes in the forest ecosystem. Based on the broad references of satellite images and LiDAR data used in environmental monitoring, quantifying the forest structure for post-mining areas is possible by using these technologies. The results of this study can serve as a reference for the development of image-based and semi-intelligent geoinformation techniques.

Fusing satellite images with LiDAR data for land use/land cover classification and deriving the spatial parameters of vegetation related to the process of monitoring progress in forest ecosystem dynamics and reclamation success, will help significantly develop comprehensive monitoring of the dynamics of novel forest ecosystem formation and forest succession mapping. Acquiring $3 \mathrm{D}$ information about biomass and carbon storage is important for post-mining forested and reclaimed areas.

The remote sensing method allows one to define the dynamics of changes occurring, as well as the direction of the expansion of vegetation. The integration of remote sensing data facilitates the definition of the spatial characteristics of vegetation to determine monitoring changes according to the reclamation process. The application of the methods of image classification and airborne laser scanning point cloud processing combined with GIS analyses provides wide possibilities in terms of automating the cyclic monitoring of LULC changes and biomass dynamics.

Author Contributions: Conceptualization, M.S., J.L.-C. and M.P.; methodology, M.S.; software, M.S.; validation, M.S.; formal analysis, M.S.; visualization, M.S.; writing-original draft preparation, M.S., J.L.-C. and M.P.; supervision, M.S., J.L.-C. and M.P. All authors have read and agreed to the published version of the manuscript.

Funding: This research was supported by project no. 2019/03/X/NZ9/00424, MINIATURA-3, National Science Centre, Poland.

Institutional Review Board Statement: Not applicable.

Informed Consent Statement: Not applicable.

Data Availability Statement: Not applicable.

Acknowledgments: Thanks to the Planet team for the account and imagery from Planet's Education and Research (E\&R) Program; Planet Application Program Interface: In Space for Life on Earth. San Francisco, CA. https: / / api.planet.com (accessed on 7 July 2021).

Conflicts of Interest: The authors declare no conflict of interest. The funders had no role in the design of the study; in the collection, analyses, or interpretation of data; in the writing of the manuscript, or in the decision to publish the results. 


\section{References}

1. Susyan, E.A.; Wirth, S.; Ananyeva, N.D.; Stolnikova, E.V. Forest succession on abandoned arable soils in European RussiaImpacts on microbial biomass, fungal-bacterial ratio, and basal CO2 respiration activity. Eur. J. Soil Biol. 2011, 47, 169-174. [CrossRef]

2. Hawryło, P.; Francini, S.; Chirici, G.; Giannetti, F.; Parkitna, K.; Krok, G.; Mitelsztedt, K.; Lisańczuk, M.; Stereńczak, K.; Ciesielski, M.; et al. The use of remotely sensed data and Polish NFI plots for prediction of growing stock volume using different predictive methods. Remote Sens. 2020, 12, 3331. [CrossRef]

3. Socha, J.; Hawryło, P.; Pierzchalski, M.; Stereńczak, K.; Krok, G.; Wężyk, P.; Tymińska-Czabańska, L. An allometric area-based approach a cost-effective method for stand volume estimation based on ALS and NFI data. Forestry 2020, 93, 344-358. [CrossRef]

4. Socha, J.; Hawryło, P.; Stereńczak, K.; Miścicki, S.; Tymińska-Czabańska, L.; Młocek, W.; Gruba, P. Assessing the sensitivity of site index models developed using bi-temporal airborne laser scanning data to different top height estimates and grid cell sizes. Int. J. Appl. Earth Obs. Geoinf. 2020, 91, 102129. [CrossRef]

5. Pietrzykowski, M.; Krzaklewski, W. Reclamation of mine lands in Poland. In Bio-Geotechnologies for Mine Site Rehabilitation; Prasad, M.N.V., Favas, P., Maiti, S.K., Eds.; Elsevier: Amsterdam, The Netherlands; Oxford, UK; Cambridge, MA, USA, 2018; Chapter 27; pp. 493-513, ISBN 978-0-12-812986-9.

6. Pietrzykowski, M. Tree species selection and reaction to mine soil reconstructed at reforested post-mine sites: Central and Eastern European experiences. Ecol. Eng. X 2019, 3, 100012. [CrossRef]

7. Pietrzykowski, M.; Daniels, W.L. Estimation of carbon sequestration by pine (Pinus sylvestris L.) ecosystems developed on reforested post-mining sites in Poland on differing mine soil substrates. Ecol. Eng. 2014, 73, 209-218. [CrossRef]

8. Pietrzykowski, M.; Woś, B.; Likus-Cieślik, J.; Świątek, B.; Pająk, M. Forest and climate change-A global view and local cases. In The Role of Agriculture in Climate Change Mitigation, 1st ed.; Pawłowski, L., Litwińczuk, Z., Zhou, G., Eds.; CRC Press: Boca Raton, FL, USA, 2020; pp. 29-39.

9. Forkuor, G.; Dimobe, K.; Serme, I.; Tondoh, J.E. Landsat-8 vs. Sentinel-2: Examining the added value of Sentinel-2's red-edge bands to land-use and land-cover mapping in Burkina Faso. GISci. Remote Sens. 2018, 55, 331-354. [CrossRef]

10. Lasanta, T.; Arnáez, J.; Pascual, N.; Ruiz-Flaño, P.; Errea, M.P.; Lana-Renault, N. Space-time process and drivers of land abandonment in Europe. Catena 2017, 149, 810-823. [CrossRef]

11. Marangoz, A.M.; Sekertekin, A.; Akcin, H. Analysis of land use land cover classification results derived from Sentinel-2 image. In Proceedings of the 17th International Multidisciplinary Scientific GeoConference Surveying Geology and Mining Ecology Management (SGEM 2017), Vienna, Austria, 27-29 November 2017; pp. 25-32.

12. Sekertekin, A.; Marangoz, A.M.; Akcin, H. Pixel-based classification analysis of land use land cover using Sentinel-2 and Landsat-8 data. Int. Arch. Photogramm. Remote Sens. Spat. Inf. Sci. 2017, 42, 91-93. [CrossRef]

13. Szostak, M.; Hawryło, P.; Piela, D. Using of Sentinel-2 images for automation of the forest succession detection. Eur. J. Remote Sens. 2018, 51, 142-149. [CrossRef]

14. Planet. 2020. Available online: https://www.planet.com/products/planet-imagery (accessed on 30 September 2020).

15. Bork, E.; Su, J. Integrating LIDAR data and multispectral imagery for enhanced classification of rangeland vegetation: A meta-analysis. Remote Sens. Environ. 2007, 111, 11-24. [CrossRef]

16. van Ewijk, K.Y.; Treitz, P.M.; Scott, N.A. Characterizing forest succession in central Ontario using lidar-derived indices. Photogramm. Eng. Remote Sens. 2011, 77, 261-269. [CrossRef]

17. Falkowski, M.; Jeffrey, S.; Evans, J.; Martinuzzi, S.; Gessler, P.; Hudak, A. Characterizing forest succession with lidar data: An evaluation for the Inland Northwest, USA. Remote Sens. Environ. 2009, 113, 946-956. [CrossRef]

18. Singh, K.; Vogler, J.; Shoemaker, D.; Meentemeyer, R. LiDAR-Landsat data fusion for large-area assessment of urban land cover: Balancing spatial resolution, data volume, and mapping accuracy. ISPRS J. Photogramm. Remote Sens. 2012, 74, 110-121. [CrossRef]

19. Axelsson, P. DEM generation from laser scanner data using adaptive TIN models. Int. Arch. Photogramm. Remote Sens. 2000, 33, 203-210.

20. Andersen, H.E.; Reutebuch, S.E.; McGaughey, R.J. A rigorous assessment of tree height measurements obtained using airborne lidar and conventional field methods. Can. J. Remote Sens. 2006, 32, 355-366. [CrossRef]

21. Hyyppä, J.; Hyyppä, H.; Litkey, P.; Yu, X.; Haggrén, H.; Rönnholm, P.; Pyysalo, U.; Pitkanen, J.; Maltamo, M. Algorithms and methods of airborne laser-scanning for forest measurements. In Laser-Scanners for Forest and Landscape Assessment, Proceedings of the ISPRS Working Group VIII/2Thies, Freiburg, Germany, 3-6 October 2004; Koch, M., Spiecker, B., Weinacker, H., Eds.; International Archives of Photogrammetry, Remote Sensing, and the Spatial Information Sciences: Freiburg, Germany, 2004; Volume XXXVI8/W2.

22. Maier, B.; Tiede, D.; Dorren, L. Characterizing mountain forest structure using landscape metrics on LIDAR-based canopy surface models. In Cartography from Pole to Pole; Springer Science and Business Media: Heidelberg, Germany, 2008; pp. 625-643.

23. McGaughey, R.J.; Carson, W.; Reutebuch, S.; Andersen, H.E. Direct measurement of individual tree characteristics from lidar data. In Proceedings of the Annual ASPRS Conference, Denver, CO, USA, 23-28 May 2004.

24. Naesset, E. Predicting forest stand characteristics with airborne scanning laser using a practical two-stage procedure and field data. Remote Sens. Environ. 2002, 80, 88-99. [CrossRef]

25. Naesset, E.; Okland, T. Estimating tree height and tree crown properties using airborne scanning laser in a boreal nature reserve. Remote Sens. Environ. 2002, 79, 105-115. [CrossRef] 
26. Wężyk, P.; Szostak, M.; Tompalski, P.; Zajączkowski, G. The role of Airborne Laser scanning in updating and revision of GIS databases-A case study in the Polish State Forest (Chojna District). In Proceedings of the 10th International Conference on LiDAR Applications for Assessing Forest Ecosystems (Silvaster 2010), Freiburg, Germany, 14-17 September 2010.

27. Wężyk, P.; Tompalski, P.; Szostak, M.; Glista, M.; Pierzchalski, M. Describing the selected canopy layer parameters of the Scots pine stands using ALS data. In Proceedings of the 8th International Conference on LiDAR Applications in Forest Assessment and Inventory, Edinburgh, UK, 17-19 September 2008; pp. 636-645.

28. EU Biodiversity Strategy. 2011. Available online: https:/ / ec.europa.eu/ (accessed on 30 September 2020).

29. National Program for Increasing Woodness. Document Adopted for Implementation by a Resolution of the Council of Ministers in June 1995, Updated in 2003. Ministry of the Environment, Warsaw; 2003. Available online: https:/ /www.gov.pl (accessed on 30 September 2020).

30. Main Statistical Office Poland. Statistical Books of Forestry. 2018. Available online: https://stat.gov.pl/obszary-tematyczne/ roczniki-statystyczne/roczniki-statystyczne/rocznik-statystyczny-lesnictwa-2020,13,3.html (accessed on 30 September 2020).

31. Hościło, A.; Mirończuk, A.; Lewandowsk, A. Determination of the actual forest area in Poland based on the available spatial datasets. Sylwan 2016, 160, 627-634.

32. Jabłoński, M.; Mionskowski, M.; Budniak, P. Forest area in Poland based on national forest inventory. Sylwan 2018, 162, 365-372.

33. Karol, B. Using of PlanetScope Satellite Images to Determine Land Cover Classes on a Former Sulfur Mines "Machów" and "Jeziórko". Master's Thesis, University of Agriculture in Krakow, Kraków, Poland, 2020.

34. Likus-Cieślik, J.; Pietrzykowski, M. Vegetation development and nutrients supply of trees in habitats with high sulfur concentration in reclaimed former sulfur mines Jeziórko (Southern Poland). Environ. Sci. Pollut. Res. 2017, 24, 20556-20566. [CrossRef]

35. Likus-Cieślik, J.; Pietrzykowski, M.; Śliwińska-Siuśta, M.; Krzaklewski, W.; Szostak, M. A preliminary assesment of soil sulfur contamination and vegetations in the vicinity of former boreholes on the afforested post-mine site Jeziórko. Geol. Geophys. Environ. 2015, 41, 371-380. [CrossRef]

36. Likus-Cieślik, J.; Pietrzykowski, M.; Szostak, M.; Szulczewski, M. Spatial distribution and concentration of sulfur in relation to vegetation cover and soil properties on a reclaimed sulfur mine site (Southern Poland). Environ. Monit. Assess. 2017, $189,87$. [CrossRef] [PubMed]

37. Macdonald, S.E.; Landhäusser, S.M.; Skousen, J.; Franklin, J.; Frouz, J.; Hall, S.; Jacobs, D.F.; Quideau, S. Forest restoration following surface mining disturbance: Challenges and solutions. N. For. 2015, 46, 703-732. [CrossRef]

38. Gołda, T. Uwarunkowania prac rekultywacyjnych w kopalni siarki "Jeziórko" w wyniku wywołanych przekształceń w środowisku glebowo-wodnym: Próba syntetycznej oceny. Inżynieria Środowiska 2003, 8, 29-43. (In Polish)

39. Stefan, K.; Fürst, A.; Hacker, R.; Bartels, U. Forest Foliar Condition in Europe. Forest Foliar Coordinating Centre in cooperating with the Australian Federal Forest Research Centre; EC-UN/ECE-FBV A: Brussels, Geneva, 1997.

40. Planet's Education and Research (E\&R) Program; Planet Team. Planet Application Program Interface: In Space for Life on Earth. San Francisco, CA. 2017. Available online: https: / / api.planet.com (accessed on 30 September 2020).

41. McGaughey, R.J. Fusion/Ldv: Software for Lidar Data Analysis and Visualization; US Department of Agriculture, Forest Service: Washington, DC, USA; Pacific Northwest Research Station: Seattle, WA, USA, 2012.

42. Knapik, K. Determination of Spatial Structure of Vegetation for the Reclaimed Former Sulfur Mine "Jeziórko" Based on Airborne Laser Scanning Point Clouds. Master's Thesis, University of Agriculture in Krakow, Kraków, Poland, 2019.

43. Szostak, M.; Knapik, K.; Likus-Cieślik, J.; Wężyk, P.; Pietrzykowski, M. Fusing Sentinel-2 imagery and ALS Point Clouds for defining the LULC changes ongoing on reclaimed areas by afforestation. Sustainability 2019, 11, 1251. [CrossRef]

44. Szostak, M.; Pietrzykowski, M.; Likus-Cieślik, J. Reclaimed area land cover mapping using Sentinel-2 Imagery and LiDAR Point Clouds. Remote Sens. 2020, 12, 261. [CrossRef]

45. Chowdhury, S.; Chao, D.K.; Shipman, T.C.; Wulder, M.A. Utilization of Landsat data to quantify land-use and land-cover changes related to oil and gas activities in West-Central Alberta from 2005 to 2013. GISci. Remote Sens. 2017, 54, 700-720. [CrossRef]

46. Farrand, W.H.; Harsanyi, J.C. Mapping the distribution of mine tailings in the Coeur d'Alene River Valley, Idaho, through the use of a constrained energy minimization technique. Remote Sens. Environ. 1997, 59, 64-76. [CrossRef]

47. Pitblado, J.R.; Amiro, B.D. Landsat mapping of the industrially disturbed vegetation communities of Sudbury, Canada. Can. J. Remote Sens. 2014, 8, 17-28. [CrossRef]

48. Pouliot, D.; Latifovic, R. Land change attribution based on Landsat time series and integration of ancillary disturbance data in the Athabasca oil sands region of Canada. GISci. Remote Sens. 2016, 53, 382-401. [CrossRef]

49. Powers, R.P.; Hermosilla, T.; Coops, N.C.; Chen, G. Remote sensing and object-based techniques for mapping fine-scale industrial disturbances. Int. J. Appl. Earth Obs. Geoinf. 2015, 34, 51-57. [CrossRef]

50. Townsend, P.; Helmers, D.; Kingdon, C.; McNeil, B.; de Beurs, K.; Eshleman, K. Changes in the extent of surface mining and reclamation in the Central Appalachians detected using a 1976-2006 LANDSAT time series. Remote Sens. Environ. 2009, 113, 62-72. [CrossRef]

51. Szostak, M.; Wężyk, P.; Pająk, M.; Hawryło, P.; Lisańczuk, M. Determination of the spatial structure of vegetation on the repository of the mine Fryderyk in Tarnowskie Góry, based on airborne laser scanning from the ISOK project and digital orthophotomaps. Geod. Cartogr. 2015, 64, 87-99. [CrossRef] 
52. Szostak, M.; Furgała, T.; Knapik, K. Landscape monitoring of post-industrial area using LiDAR point clouds and Sentinel-2 images. In Proceedings of the 19th International Multidisciplinary Scientific Geoconference SGEM Conference (SGEM 2019), Albena, Bulgaria, 28 June-7 July 2019; pp. 431-438. [CrossRef]

53. Osińska-Skotak, K.; Radecka, A.; Piórkowski, H.; Michalska-Hejduk, D.; Kopeć, D.; Tokarska-Guzik, B.; Ostrowski, W.; Kania, A.; Niedzielko, J. Mapping succession in non-forest habitats by means of remote sensing: Is the data acquisition time critical for species discrimination? Remote Sens. 2019, 11, 2629. [CrossRef]

54. Wężyk, P.; Szostak, M.; Krzaklewski, W.; Pająk, M.; Pierzchalski, M.; Szwed, P.; Hawryło, P.; Ratajczak, M. Landscape monitoring of post-industrial areas using LiDAR and GIS technology. Geod. Cartogr. 2015, 64, 125-137. [CrossRef]

55. Alvarenga, P.; Clemente, R.; Garbisu, C.; Becerril, J.M. Indicators for monitoring mine site rehabilitation. In Bio-Geotechnologies for Mine Site Rehabilitation; Prasad, M.N., Favas, P.J.C., Maiti, S.K., Eds.; Elsevier: Amsterdam, The Netherlands, 2018 ; pp. 49-66.

56. Favas, P.J.C.; Martino, L.E.; Prasad, M.N.V. Abandoned mine land reclamation-Challenges and opportunities (holistic approach). In Bio-Geotechnologies for Mine Site Rehabilitation; Prasad, M.N., Favas, P.J.C., Maiti, S.K., Eds.; Elsevier: Amsterdam, The Netherlands, 2018; pp. 3-31.

57. Gatica-Saavedra, P.; Echeverría, C.; Nelson, C.R. Ecological indicators for assessing ecological success of forest restoration: A world review. Restor. Ecol. 2017, 25, 850-857. [CrossRef]

58. Wang, J.; Wei, Z.; Wang, O. Evaluating the eco-environment benefit of land reclamation in the dump of an opencast coal mine. Chem. Ecol. 2017, 33, 607-624. [CrossRef]

59. Bradshaw, A.D.; Hüttl, R. Future minesite restoration involves a broader approach. Ecol. Eng. 2001, 17, 87-90. [CrossRef]

60. Pietrzykowski, M.; Krzaklewski, W. An assessment of energy efficiency in reclamation to forest. Ecol. Eng. 2007, 30, 341-348. [CrossRef]

61. Pietrzykowski, M.; Krzaklewski, W.; Woś, B.; Pietrzak, W. Ocena zagospodarowania leśnego zrekultywowanych terenów po otworowej eksploatacji siarki. Przegląd Górniczy, Miesięcznik Stowarzyszenia Inżynierów i Techników Górnictwa 2012, 7, 98-103. (In Polish)

62. Pietrzykowski, M.; Woś, B.; Haus, M. Scots pine needles macro-nutrient (N, P, K, Ca, Mg, and S) supply at different reclaimed mine soil substrates-As an indicator of the stability of developed forest ecosystems. Environ. Monit. Assess. 2013, 185, 7445-7457. [CrossRef]

63. Szostak, M.; Wężyk, P.; Hawryło, P.; Pietrzykowski, M. The analysis of spatial and temporal changes of land cover and land use in the reclaimed areas with the application of airborne orthophotomaps and LANDSAT images. Geod. Cartogr. 2015, 64, 75-86. [CrossRef]

64. Szostak, M.; Likus-Cieślik, J.; Knapik, K.; Wężyk, P.; Pietrzykowski, M. Analysis of land use and land cover classes for the afforested post-mine site using Sentinel-2 images. In Proceedings of the 18th International Multidisciplinary Scientific GeoConference Surveying Geology and Mining Ecology Management (SGEM 2018), Albena, Bulgaria, 30 June-9 July 2018 ; Volume 18, pp. 41-48. [CrossRef]

65. Szostak, M.; Likus-Cieślik, J.; Knapik, K.; Wężyk, P.; Pietrzykowski, M. Monitoring the spatial range of forested areas in the reclaimed sites using Sentinel-2 images. Sylwan 2019, 163, 55-61.

66. Kolecka, N.; Kozak, J.; Kaim, D.; Dobosz, M.; Ginzler, C.; Psomas, A. Mapping secondary forest succession on abandoned agricultural land with LiDAR point clouds and terrestrial photography. Remote Sens. 2015, 7, 8300-8322. [CrossRef]

67. Szostak, M. Automated land cover change detection and forest succession monitoring using LiDAR Point Clouds and GIS analyses. Geosciences 2020, 10, 321. [CrossRef]

68. Vastaranta, M.; Wulder, M.A.; White, J.C.; Pekkarinen, A.; Tuominen, S.; Ginzler, C.; Kankare, V.; Holopainen, M.; Hyyppä, J.; Hyyppä, H. Airborne laser scanning and digital stereo imagery measures of forest structure: Comparative results and implications to forest mapping and inventory update. Can. J. Remote Sens. 2013, 39, 382-395. [CrossRef]

69. Ostrowski, W.; Górski, K.; Pilarska, M.; Salach, A.; Bakuła, K. Comparison of the laser scanning solutions for the unmanned aerial vehicles. Arch. Photogramm. Cartogr. Remote Sens. 2017, 29, 101-123. [CrossRef]

70. Osińska-Skotak, K.; Jełowiecki, Ł.; Bakuła, K.; Michalska-Hejduk, D.; Wylazłowska, J.; Kopeć, D. Analysis of using dense image matching techniques to study the process of secondary succession in non-forest natura 2000 habitats. Remote Sens. 2019, 11, 893. [CrossRef]

71. White, J.; Stepper, C.; Tompalski, P.; Coops, N.; Wulder, M. Comparing ALS and image-based point cloud metrics and modelled forest inventory attributes in complex coastal forest environment. Forests 2015, 6, 3704-3732. [CrossRef]

72. White, J.; Wulder, M.; Vastaranta, M.; Coops, N.; Pitt, D.; Woods, M. The utility of image-based point clouds for forest inventory: A comparison with airborne laser scanning. Forests 2013, 4, 518-536. [CrossRef]

73. Koska, B.; Jirkab, V.; Urbana, R.; Kremena, T.; Hesslerovab, P.; Jona, J.; Pospisila, J.; Fogl, M. Suitability, characteristics, and comparison of an airship UAV with lidar for middle size area mapping. Int. J. Remote Sens. 2017, 38, 2973-2990. [CrossRef]

74. Moudrý, V.; Gdulová, K.; Fogl, M.; Klápště, P.; Urban, R.; Komárek, J.; Moudrá, L.; Štroner, M.; Barták, V.; Solský, M. Comparison of leaf-off and leaf-on combined UAV imagery and airborne LiDAR for assessment of a post-mining site terrain and vegetation structure: Prospects for monitoring hazards and restoration success. Appl. Geogr. 2019, 104, 32-41. [CrossRef]

75. Urban, R.; Koska, B.; Moudry, V.; Solsky, M. Terrain of post mining site from airship lidar. In Proceedings of the 16th International Multidisciplinary Scientific GeoConference (SGEM 2016), Albena, Bulgaria, 30 June-6 July 2016; Volume 2, pp. 577-584. [CrossRef] 
76. Ai, J.; Zhang, C.; Chen, L.; Li, D. Mapping annual land use and land cover changes in the Yangtze estuary region using an object-based classification framework and Landsat time series data. Sustainability 2020, 12, 659. [CrossRef]

77. Deng, J.; Lin, Y.; Zhou, M.; Wu, C.; Chen, B.; Xiao, G.; Cai, J. Ecosystem services dynamics response to tremendous reclamation in a coastal island city. Ecosyst. Health Sustain. 2019, 5, 155-168. [CrossRef]

78. Zhao, Y.; Li, X.; Zhang, P.; Hu, Y.; Huang, L. Effects of vegetation reclamation on temperature and humidity properties of a dumpsite: A case study in the open pit coal mine of Heidaigou. Arid Land Res. Manag. 2015, 29, 375-381. [CrossRef] 